\title{
FRACTALIDADE E TROCA DE PERSPECTIVAS
}

J osé A ntonio Kelly Luciani

\section{Introdução*}

Pouco tempo após se envolver com a antropologia, a pessoa depara-se com um aparente paradoxo. Os antropólogos são, de um lado, fascinados pela recorrência de padrões sociais; de outro, mostram-se céticos ou desconfortáveis quanto a elucidar esses padrões sob a forma de um sistema. Enfatizam, pois, ao mesmo tempo, regularidade e imprevisibilidade, as similaridades da humanidade e a particularidade do sujeito humano, determinismo e caos. É por isso que a idéia de fractalidade - padrões escalares auto-similares [self-similar scaled patterns] que podem emergir de sistemas caóticos - pode revelar-se tão atrativa. Que outra imagem caracterizaria melhor o projeto antropológico?

Neste ensaio, exploro o potencial da idéia de fractalidade juntamente com uma de suas propriedades, a auto-similaridade escalar [scaled self-similarity], e proponho a noção de personitude [personhood] fractal como modo de pensar a pessoa ameríndia. Quando falo de personitude fractal, estou enfatizando tanto o encerramento de pessoas inteiras em partes de pessoas quanto a replicação de relações entre Eus [selves] e Outros [alters] em diferentes escalas (intrapessoal, interpessoal e intergrupal): dois lados de uma mesma moeda1.

Meu método consiste em fundir aspectos de duas teorias antropológicas desenvolvidas em regiões distantes: a idéia do "divíduo" melanésio (Strathern 1988) e a idéia do perspectivismo ameríndio (Viveiros de Castro 1998)2, usando como gancho o fio da relacionalidade, isto é, a constituição relacional de pessoas e contextos. Este é um exercício de "melanesianizar" a A mazônia, destacando os elementos de troca-dom que sustentariam uma ontologia perspectivista, cujo propósito é abrir um campo de interpretação para certos temas amazônicos bem conhecidos. Trata-se, antes de tudo, de um experimento: o leitor fica assim avisado 
de que o objetivo deste texto é sugerir conexões mais que apresentar verdadeiras descobertas.

Basearei minha análise na comparação de três grupos ameríndios situados no Brasil: os A raweté, um povo de língua tupi-guarani, caçadorhorticultor, do qual hoje existe apenas uma aldeia no médio Ipixuna (um tributário do rio Xingu, no Estado do Pará); os célebres Tupinambá, da mesma família lingüística, habitantes da costa brasileira na época da conquista portuguesa; e, finalmente, os Wari' (também conhecidos na literatura como Pakaa N ova), da família lingüística Txapacura, que vivem no oeste do Estado de Rondônia. Alguma referência também é feita aos A chuar do conjunto jívaro, na A mazônia equatoriana e peruana. $O$ fio utilizado para ligar esses grupos são os temas da guerra e do canibalismo humano ou divino3. O leitor também deve ser alertado de que, enquanto os dados sobre os A raweté e Wari' são extraídos de suas respectivas etnografias, o material que uso para os Tupinambá tem um estatuto diferente: proveniente não de fontes históricas diretas, mas da análise de Viveiros de Castro em From the Enemy's Point of View, é inevitavelmente afetado pelas interpretações desse autor. A lém disso, algumas das afirmações relativas aos Tupinambá devem ser lidas não como fatos, mas como sugestões analíticas.

Este exercício compreende três passos. Primeiro, apresentarei uma discussão sucinta de duas proposições sobre a socialidade ameríndia comumente encontradas na literatura: a natureza contextual das categorias "nós/eles" e a dependência de relações com o exterior, de relações com outros, para a reprodução social. Esses dois aspectos me permitem introduzir a figura analítica da pessoa relacionalmente dual. Em segundo lugar, apresentarei duas versões alternativas de como "outros" se tornam "nós", de como fronteiras são cruzadas e o potencial do exterior para a reprodução é realizado: de um lado, a troca de partes do corpo, que faz pensar as relações entre Eus e Outros como mediada pela troca; de outro, certos aspectos de uma teoria do perspectivismo com uma incidência específica sobre o corpo. Essa apresentação sublinha o papel do corpo e de suas modificações na sustentação das relações entre o Eu [Self] e o Outro. O último passo constitui o núcleo deste ensaio, onde examino em mais detalhe os três exemplos ameríndios. Descrever o funcionamento tanto da troca de partes do corpo como das modificações corporais enquanto dois passos de um processo perspectivista pode parecer desajeitado, mas foi dessa maneira (tentando conciliar as teorias da troca e do perspectivismo) que cheguei à idéia dos fractais como heurística. Em certo sentido, pois, este ensaio conta sua própria história. 


\title{
Alguns temas ameríndios
}

Foi notado há muito tempo (Seeger et alii 1979) que as sociedades ameríndias conferem prioridade à identidade, mais do que à solidariedade jurídica ou econômica, como o principal referente da organização social. Trabalhos posteriores revelam - na economia política (Rivière 1984), na escatologia e práticas funerárias (Carneiro da Cunha 1978; Vilaça 1992; Viveiros de Castro 1992), na organização social e sistemas de nominação (Maybury-Lewis 1979) - a operação da "simbólica do idêntico e do diferente" na socialidade ameríndia, sob diversas vestes contextuais:

\author{
Eu : Outro : : Consangüíneos : Afins \\ Vivos : Mortos \\ Nós : Inimigos \\ Predador : Presa \\ Humano : Divino \\ Masculino : Feminino
}

Estas oposições, na medida em que são básicas, não são estáticas. Quem é Eu e quem é Outro depende de quem está sendo comparado. A dinâmica dessa categorização é resumida no uso araweté do termo bïdẹ:

"A oposição bïde $x$ awĩ é a forma forte de uma oposição central no pensamento araweté: bïde, 'nós', 'a gente', e amite, 'outro', 'os outros'. A mite [outro, não-parente] não é uma categoria de pessoa, mas uma posição, a de alteridade em relação a um pólo não-marcado, um 'outro' versus um 'mesmo'". (Viveiros de Castro 1992:64-65)

Isso se assemelha ao emprego do termo jívaro shuar:

“Esta expressão se refere a um conjunto multinivelado de relações entre termos contrastivos: assim, segundo o contexto, o termo shuar se refere à 'minha parentela bilateral' em oposição a outras, 'meu grupo local' em oposição a outros grupos territoriais, 'A chuar' em oposição a outras unidades tribais jívaro, 'J ívaro' em oposição a brancos ou outros índios, e assim por diante." (Taylor 1996:204).

Uma outra proposição bem estabelecida no campo americanista é a dependência simbólica em relação ao exterior para a reprodução social (Fausto 2000). Disso temos vários exemplos. Para os Wari', o sangue de 
um inimigo morto é incorporado pelo matador e se transforma em sêmen que vai "engordar" sua esposa: "[e]fetivamente, [...] o matador terá um filho: o jam [alma] do inimigo morto." (Vilaça 1992:103-104) Com o tratamento ritual da tsantsa jívaro, a cabeça do inimigo morto, esperava-se produzir no ano seguinte uma criança entre os parentes do matador (Descola 1997:276). No caso dos Tupinambá, poder-se-ia, com base na interpretação de Viveiros de Castro, esperar uma associação similar. Através da execução de um inimigo, da incorporação simbólica de seu sangue e da aquisição concomitante de novos nomes e de uma identidade pessoal [selfhood] renovada, os rapazes atingiam o estatuto de pessoas plenas, que apenas então poderiam casar-se e ter filhos legítimos (ver Viveiros de Castro 1992:151). Além disso, é possível sugerir, com base em dados existentes para outros grupos, que esses nomes fossem estreitamente associados à alma do inimigo. Mantenhamos pois em mente essas proposições.

A natureza relacional do divisor canônico Eu/Outro, juntamente com as passagens de Outro a Eu que têm que ocorrer devido à necessidade do exterior para a reprodução social, permitem-nos avançar a sugestão analítica de que, capazes de tomar as posições de Eu e de Outro, pessoas são constituídas como relacionalmente duais. Dessa maneira, podem ser vistas como compósitos de Eu/Outro - ou nós/inimigos, consangüíneo/ afim, predador/presa, e assim por diante. Uma segunda derivação analítica, tomando emprestado de M. Strathern, é que a pessoa é divisível: em certos contextos, sua integridade pode ser rompida (ainda que por extração forçada). É em virtude dessas duas condições - dualidade e divisibilidade - , então, que pessoas podem assumir ou ser forçadas a assumir uma posição em um dos lados do divisor canônico Eu/Outro.

Do ponto de vista de uma teoria da troca, poder-se-ia propor ser a troca simbólica ou real de partes da pessoa o que permite atravessar o divisor canônico. A passagem é mediada por uma transação: o inimigo dá sempre uma parte de si mesmo. Assim, em um sentido stratherniano, sangue/cabeças tornam-se partes transacionáveis das pessoas. Um duplo jogo de metáfora e metonímia parece estar em ação: de um lado, partes do Outro são incorporadas, o Outro é um Eu metafórico; de outro, partes de outras pessoas se tornam pessoas: os filhos dos matadores wari' e jívaro, o novo nome (alma?) do matador tupinambá.

Poderíamos também pensar em uma formulação alternativa, a partir de certos aspectos de uma teoria do perspectivismo ameríndio (Viveiros de Castro 1998). A natureza posicional do divisor Eu/Outro requer meios de diferenciação, de clara demarcação de quem é quem. O perspectivis- 
mo como teoria ilumina a concepção indígena do corpo e de sua relação com a dinâmica da identidade e alteridade.

A ontologia perspectivista ameríndia pode ser vista como "multinaturalista" : supõe uma subjetividade bruta que constrói suas múltiplas realidades objetivas (naturezas). A consciência comum a diversas espécies e aos humanos dá a todos uma perspectiva sobre o mundo. Pessoas são, pois, definidas como sujeitos potenciais, aqueles com acesso a um ponto de vista. Ter uma perspectiva confere a animais e plantas uma "humanidade" pela qual vêem a si mesmos da mesma maneira como os humanos se vêem: jaguares têm esposas, filhos, clãs, casas, e festejam do mesmo modo que os humanos. E, todavia, um jaguar, enquanto predador, verá um humano como presa (por exemplo, um porco-do-mato), na mesma medida em que o porco-do-mato, como presa, verá um humano como predador (por exemplo, um jaguar). O ponto é que jaguares, porcos e humanos vêem as coisas da mesma maneira, mas o que eles vêem é diferente, e depende da perspectiva: humanos podem ver a si mesmos como sujeitos (cultura), mas são ao mesmo tempo o objeto (natureza) de outra subjetividade, e vice-versa. A passagem de sujeito a objeto é uma mudança de posição, de perspectiva. Conseqüentemente, o conteúdo de categorias tais como sujeito/objeto ou natureza/cultura não é estático, mas relacional.

Nesse mundo perspectivista, é o corpo que funciona como o principal diferenciador. Para além do bem documentado foco ameríndio na fabricação, modificação e destruição de corpos (Seeger et alii 1979), o corpo como locus de diferenciação é também sede de perspectiva. $O$ que você vê, o mundo que você constrói, depende do corpo que você tem (Viveiros de Castro 1998:478). Corpos parecem ser concebidos como vestimentas que podem ser trocadas (Rivière 1994), não, todavia, para encobrir uma realidade interna: novas vestes, isto é, corpos modificados, trazem novas capacidades. $M$ as, então, o corpo precisa ser entendido não como o aspecto material da pessoa, o ser físico, e sim, antes, como "feixe de afecções", um conjunto de capacidades e comportamentos típicos de um ser (Viveiros de Castro 1998:478).

Uma teoria perspectivista integra a importância dos nomes e a da decoração corporal. São, parcialmente, nomes e ornamentos que permitem a sustentação de uma ontologia perspectivista em face da fixidez das peles humana e animal. Eles se tornam evidência da divisibilidade e da natureza dual das pessoas, fazendo do corpo um objeto social par excellence, um substituto perfeito da troca material (Turner 1995:147).

$M$ as parece que nos deparamos com um problema. Dissemos que a troca de partes do corpo serve como um meio de cruzar o divisor Eu/Ou- 
tro. Uma teoria perspectivista, contudo, mostra como o corpo é a sede da perspectiva e como sua modificação é o que efetua mudanças de posição. Embora toda troca de partes corporais seja uma modificação corporal, implicando que a última inclui a primeira, argumentarei que essa troca de partes do corpo desempenha um papel distinto na sustentação de uma ontologia perspectivista.

\section{A fractalidade vista de perto}

Permitam-me agora sugerir de que maneira a idéia de fractalidade pode fazer convergir uma teoria da troca e uma teoria do perspectivismo, no exame de três casos que iluminam aspectos diferentes desse encontro. Primeiro, vamos explicitar os pressupostos desta análise.

1) Pessoas são seres duais, residindo essa dualidade na possibilidade de assumir posições em ambos os lados do divisor canônico Eu/Outro. Em uma ontologia perspectivista, é precisamente isto que define uma pessoa, humana ou não humana: pessoas são esses seres duais sujeito/objeto a que se credita perspectiva e agência (participam da cultura e têm uma alma imortal), mas que ao mesmo tempo são objeto de outra subjetividade (parte da natureza de alguém). Lembremos quantos dos animais capazes de fazer dos humanos suas presas são pessoas (ver Vilaça 1992:59-64 para um exemplo wari'). A consciência de uma pessoa de sua dualidade sujeito-Eu/objeto-O utro expressa-se, principalmente, no seu reconhecimento da possibilidade de se tornar presa de alguém4. Pessoas, portanto, não são nem objeto nem sujeito, mas ambos: o ponto de encontro de um Eu reflexivo e da perspectiva do Outro. O contexto determinará quanto a qualidade-de-sujeito [subjectness] ou a qualidade-deobjeto [objectness] será prevalecente em uma relação. E, ponto importante, tornar-se um Outro (uma outra pessoa) não é des-subjetivante, mas sim alterante [Othering], implicando, portanto, uma mudança de perspectiva. Tais mudanças requerem uma transferência de partes do corpo e outras modificações (isto será detal hado adiante). Todavia, há também posições não reversíveis, como no caso dos deuses araweté que mantêm sua perspectiva dominante de predadores (Viveiros de Castro 1992:254; 1998:485). Isso define a sobrenatureza: os deuses araweté nunca são devorados (nunca são presa), eles são puro sujeito5. No outro extremo encontrase a natureza, ou seja, animais sem alma, plantas e coisas que são sempre presa ou puro objeto (o que não significa que não sejam submetidos à dinâmica do perspectivismo: o sangue humano pode ser o cauim do jaguar). 
2) Adotando uma visada stratherniana, isto é, o ponto de vista do dom, vejamos as pessoas como divíduos: aqui a dualidade é evidenciada pela possibilidade de anexar e desanexar partes de pessoas em relações de troca. Meu uso da idéia de pessoas divisíveis não é um capricho analítico. A natureza partível da pessoa amazônica requer pouca demonstração $0^{6}$. Para além dos casos já mencionados, podemos lembrar como as crianças araweté e achuar têm uma alma não completamente anexada ou fixada no corpo, o que as torna suscetíveis à doença. Em geral, muitas das restrições da couvade, comuns na Amazônia, têm como premissa a fragilidade da integração corpo-alma (ver Viveiros de Castro 1992:183; Descola 1997:233). Doenças (em qualquer idade) e o ato de matar tendem a afrouxar o laço corpo-alma. Creio que os comentários de Viveiros de Castro a propósito dos Araweté se aplicam a vários outros grupos: “[q]ualquer um que não tenha ainda consciência ou que tenha caído inconsciente encontra-se em perigo: ou ainda não é um ser humano completo, ou está prestes a deixar de sê-lo" (Viveiros de Castro 1992:194). Lembremos também a ampla difusão de motivos como a perda da alma e os aspectos da pessoa que aparecem em sonhos e aos quais se atribui independência do sujeito.

Bem, uma pessoa não dividida sempre participa das relações como um termo, isto é, uma pessoa cuja qualidade-de-sujeito é posta em primeiro plano pela certeza de ser um transator em um relacionamento de troca, em oposição a uma pessoa dividida que participa enquanto significante, operador de uma relação7. Operadores, segundo Gell (1999) e Strathern (1992), constituem a "objetificação de uma relação", um valor puramente relacional, pessoas cuja qualidade-de-objeto é posta em primeiro plano pela certeza de estarem sendo transacionadas. A marca da personitude é assim a possibilidade de transacionar e ser transacionado; a marca da condição divina é a impossibilidade de ser transacionado: pode-se trocar com os deuses, mas os deuses jamais são trocados.

Nessa tentativa de reunir perspectivismo e teoria da troca, não se pode confundir os termos: quando falamos de sujeitos em uma teoria perspectivista nos referimos a um agente com uma visão sobre o mundo. Isto não é o oposto de uma pessoa transacionada que objetifica uma relação (um operador). Um inimigo cativo não perde sua perspectiva sobre o mundo. De fato, sua perspectiva é justamente o que o faz valioso para seu captor. Assim, mesmo quando é a parte transacionada, em um sentido stratherniano, ele é também "o objeto das relações" entre inimigos. Em suma, sua perspectiva (qualidade-de-sujeito) é o objeto das trocas. Um operador é um objeto temporário das partes transacionantes. De modo correspondente, termos são sujeitos temporários com respeito à parte transacio- 
nada. Depois da transação, todos reassumem sua qualidade "normal" de pessoas sujeito/objeto; como foi sugerido acima, e como será detalhado abaixo, o Outro é englobado pelo Eu, o inimigo é englobado pelo matador.

O englobamento através da troca de uma parte da pessoa leva-nos à qualidade fractal a que quero me referir: o encerramento do todo (de uma pessoa) na parte (de uma pessoa); a conversão de partes de pessoas em pessoas inteiras - o filho de um matador wari', o filho de um matador jívaro e, podemos adicionar especulativamente, o novo nome (alma) do matador tupinambá. É necessário manter em mente, então, quando adiante falo em troca de partes do corpo, que o que é trocado é uma versão em escala reduzida da pessoa inteira.

3) Grupos e pessoas (humanos e não humanos) podem aparecer como uma só pessoa quando comparados com outros grupos e pessoas. “Uma pessoa" pode assim se referir a diversos indivíduos unidos pela partilha de uma posição comum em oposição a outro grupo similar. O status unitário de um grupo aponta para a noção de corpo como "feixe de afecções", como o conjunto das capacidades partilhadas por uma espécie. Nesse caso, o que é partilhada é uma posição. Consubstanciais wari' pensam em si mesmos como um corpo, ainda que existam vários participantes dessa unidade; eles também atribuem o comportamento gregário dos queixadas a seus corpos (Vilaça 1992:52). Diversos outros pontos sustentam essa idéia: guerreiros costumam tornar-se co-matadores nos ataques, e mesmo que apenas um deles tenha causado a morte do inimigo, todos os participantes são submetidos às precauções pós-homicídio (ver Descola 1997:304; Vilaça 1992:103, para exemplos achuar e wari'). No caso dos Tupinambá, os aldeões tornavam-se co-devoradores do inimigo, todos eles comiam de sua carne (Viveiros de Castro 1992:302), como que para se fazerem igualmente culpados e objetos legítimos da vingança de seus inimigos. O mesmo pode ser dito dos deuses araweté: todos comem a carne do morto quando da chegada deste no outro mundo (Viveiros de Castro 1992:211).

Tudo isso é, basicamente, uma expressão do caráter contextual das categorias nós/outros a que nos referimos antes, e uma outra expressão da fractalidade: a pessoa-como-grupo é uma versão em escal a ampliada da pessoa-como-indivíduo e uma versão duas vezes ampliada da pessoacomo-parte. $\mathrm{O}$ que se tornará evidente adiante é que a personitude fractal implica que relações entre pessoas, em qualquer escala, são réplicas umas das outras, isto é, são auto-similares.

4) Uma pessoa dividida, enquanto operador, pode significar uma ou mais das relações abaixo, constituídas pelo divisor canônico Eu/O utro (Quadro 1). 
Quadro 1: Relações significadas por uma pessoa dividida

\begin{tabular}{lll}
\hline Relação & Eu & Outro \\
Inimizade (vingança) & Nós & Inimigos \\
Afinidade & Consangüíneos/Consubstanciais & Afins \\
Predação & Predador & Presa \\
Reprodução & Masculino & Feminino \\
Morte & Divindades/Mortos & Vivos
\end{tabular}

\section{"Desembrulhando" a pessoa fractal8}

A companhar a trajetória de um inimigo tupinambá, do estado de inimizade à fusão com o matador, evidenciará a qualidade fractal das pessoas, revelando as relações que as constituem.

A pessoa é constituída por todas as relações acima mencionadas (Figura 1).

Figura 1: A constituição relacional da pessoa tupinambá ${ }^{9}$

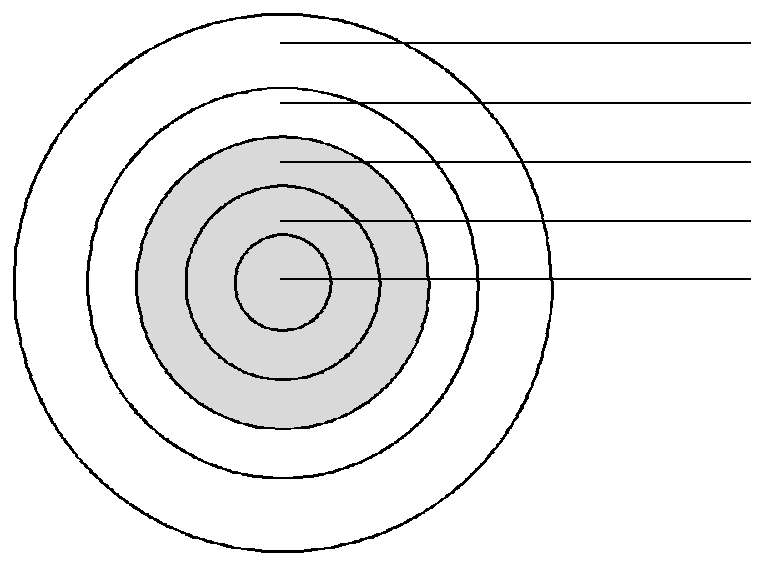

Inimizade

A finidade

Morte

Predação

Reprodução 
Quando o inimigo é capturado e trazido à aldeia do captor, ele se torna um significante da relação entre inimigos. Isso pode ser visto como o inimigo dando uma de suas partes, uma instância em escala ampliada da pessoa dando uma parte do corpo. Como tal, o cativo é uma pessoa separada ou dividida, não mais um termo mas um operador; a relação de inimizade, de vingança, foi "desembrulhada" (Figura 2).

Figura 2: A pessoa como um operador da relação entre grupos inimigos

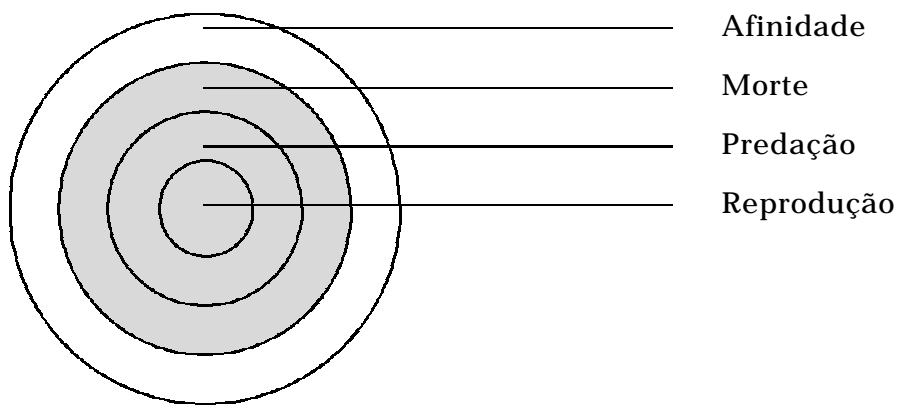

Uma vez na aldeia inimiga, o cativo podia seguir duas rotas: 1) ele poderia ser oferecido como dom aos afins de seu captor. Um recém-casado estava obrigado a fornecer cativos a seus afins mais jovens para a iniciação (de modo que estes pudessem adquirir nomes e casar-se). $O$ cativo era dado a um cunhado como contrapartida da esposa previamente recebida. N esse contexto, o cativo é uma filha de irmã para os afins do captor, mas também pode ser visto como uma contrapartida do próprio captor: um marido de irmã (Viveiros de Castro 1992:295). O que seria aparentemente uma situação recíproca de troca entre afins no grupo do captor é assim desdobrado: há dois tipos de afim, os que dão cativos e os que dão mulheres, e inimigos são do primeiro tipo. 2) o cativo podia ser também dado à irmã ou filha do captor. Aqui o inimigo ocupa a posição de tomador de esposa.

$\mathrm{Na}$ medida em que parece estar encenando a afinidade em si mesma, revelando cada uma das posições possíveis de afinidade ${ }^{10}$, o cativo tem em todas essas trocas um valor de relação, el e é um operador (uma objetificação) em relações de afinidade internas ao grupo do captor, as 
mesmas relações que o constituíram em sua própria aldeia. Dessa maneira, a relação de afinidade é "desembrulhada" (Figura 3).

Figura 3: A pessoa como um operador nas relações entre afins no interior do grupo inimigo

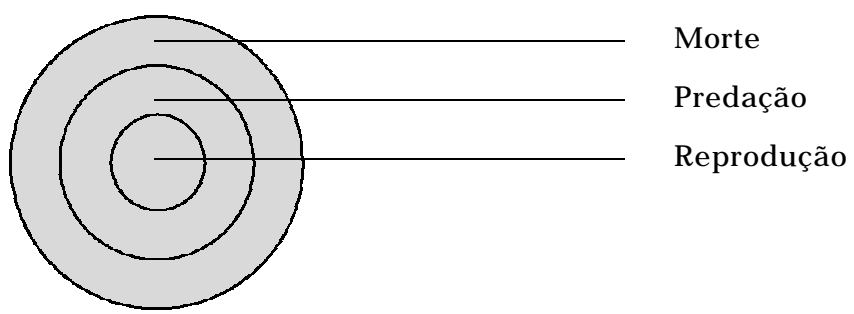

Restam ainda três relações constitutivas da pessoa do guerreiro. Estas relações "interiores" requerem a reconstituição do cativo, que deve ser outra vez feito termo, uma pessoa plena cuja qualidade-de-sujeito é o que está sendo valorizado. Ele era preparado e decorado para o rito final de execução. Em um diálogo de abertura com o matador, revelava-se um predador; sabendo-se morto, terminaria dizendo que seu povo já tinha se vingado, como se fosse ele quem estivesse para matar e não para ser morto.

“Todo o cuidado era tomado para que o ente em vias de ser comido fosse um ser humano, um ser de palavras, promessas e memórias. Inumeráveis detaIhes do rito [...] testemunham este esforço em constituir a vítima como um sujeito plenamente humano" (Viveiros de Castro 1992:292).

O cativo tomando a posição do matador - trata-se de um momento crucial de mútua identificação. O cativo representa o futuro do matador (ser executado pelo inimigo), o matador representa o passado do cativo (que foi um matador) (Viveiros de Castro 1992:291). Eles encarnam as duas facetas temporalmente deslocadas da pessoa; em uma leitura stratherniana, são duas "meias-pessoas", e juntos, "uma" pessoa. Qual dessas coisas está em jogo - a reprodução social do matador, a imortalidade do inimigo ou a continuidade de ambos - depende da perspectiva. Os Tupinambá passavam da relação com os mortos para a relação com os 
inimigos de maneira tal que os inimigos continham cada um a história do outro e eram cada um o futuro do outro. Isto é a pessoa fractal "em fabricação".

Ao ser morto, o cativo é dividido mais uma vez. Poderíamos sugerir que sua dualidade masculino/feminino é desembrulhada na distribuição das partes de seu corpo? A carne é consumida principalmente por mulheres, os crânios (ossos) são quebrados pelo matador. De tal maneira que:

\section{masculino : feminino : : ossos : carne}

Se retemos a idéia de que o nome tupinambá era um elemento divino da pessoa, uma manifestação da alma, vemos como essa dualidade humano/divino é desembrulhada na separação entre o nome (que vai com o matador) e a substância (que vai para o resto da aldeia), adicionando mais um par à associação acima:

masculino : feminino : : ossos : carne : : nomes (divino) : substância (humano)

A dualidade predador/presa do cativo era também realizada: uma óbvia presa canibal, este era também um não tão óbvio predador canibal. O matador era o único que não comia o cativo11:

“[...] afastando-se para sua casa após a pancada final, [...] aplicavam-Ihe no pulso os lábios cortados do inimigo, como se a inverter a relação canibal [...]. J ejuando por dias em sua rede, com um fio de algodão amarrado em torno de seu peito (como um cadáver?) [... ]. Finalmente, o matador era escarificado (para que o sangue não apodrecesse em sua barriga)." (Viveiros de Castro 1992:293)

Dessa maneira, as relações são desembrulhadas: a constituição relacional do cativo, sua dualidade multinivelada, é ou encenada - p. ex., quando este assume um valor puramente relacional de afinidade - , ou revelada na constituição mesma de seu ser - p. ex., nomes (divino) e substância (humano).

Finalmente, uma parte do cativo, seu sangue/nomes, tornava-se parte do executor. O matador ressuscitava com um novo nome. Poderíamos ver isso como um processo de englobamento de um Outro pelo Eu, uma mudança de posição mediada pelo sangue inimigo? $\mathrm{N}$ ote-se que nesse processo está em questão tanto a transformação do Outro em um Eu quanto o contrário. O matador é "al terado" ["othered"] de diferentes manei- 
ras: pode agora se casar legitimamente, pois foi afinizado pelo cativo; morreu e ressuscitou, o que faz dele um ser algo divino; e, o mais importante de tudo, ele se torna um inimigo. Todas as relações que foram desembruIhadas através do cativo são reconstruídas na pessoa do matador, e o lento processo do cativo no campo do inimigo pode bem ser uma exibição daquilo em tudo que o cativo vai se tornar. O matador englobou, "comeu", seu inimigo, e, no final das contas, você é o que você come. Mas, o que come o matador? Relações (ver Viveiros de Castro 1992:303) (Figura 4).

Figura 4: Reconstituição do matador pelo inimigo12
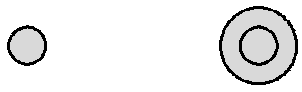

Reprodução:

o matador é

"inseminado"

pelo inimigo,

e pode agora

casar-se e

reproduzir.

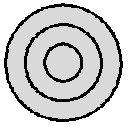

Morte: o matador morre, ressuscita e adquire nomes.

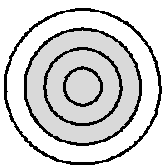

A finidade: o matador pode casar-se, agora objeto ele se torna da atenção um afim.

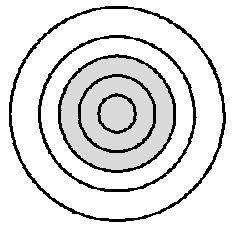

Inimizade: o matador é do inimigo, e sabe disso!

Incidentalmente, essa descrição deixa claro como uma pessoa apenas contém relações das quais ele/ela participou. Você só pode tomar uma posição se você a contém. É por isso que o matador tem que morrer; participando em uma relação de morte, ele se torna imortal. Isso também dá aos matadores, quando capturados (inimigos), a capacidade de significar a imortalidade no desembrulho e transmissão de seu elemento divino: seus nomes.

Vamos discutir agora um caso araweté, onde podemos ver, no processo de morte da pessoa, um desembrulho similar. As relações que os Tupinambá mantinham com seus inimigos, os Araweté sustentam com seus deuses Maï.

Quando um Araweté morre, sua pessoa sofre uma série de transformações. Seu corpo apodrece, processo que é compreendido como de con- 
sumo canibal por parte de dois tipos de espírito, os Ãñi e I wi yari, a A vó Terra. Seu í, um princípio vital evidenciado em vida pela pulsação sangüínea e pela imagem da pessoa, divide-se e toma dois caminhos. Um de seus aspectos torna-se um ta'o we, um espectro, um duplo do cadáver, uma espécie de corpo mecânico desprovido de subjetividade. Este ser perdura o tempo de decomposição da pessoa, transformando-se em "algo como um gambá morto", e então em um macaco-da-noite. Esse aspecto corresponde à parte do ĩ que em vida estava associado à sombra da pessoa. A visão de um ta'o we pode causar a morte. São temidos pelos vivos, que após uma morte se afastam da aldeia até suspeitarem de que o tá'o we deixou de existir. $\mathrm{O}$ outro aspecto do $\tilde{\mathrm{i}}$, que corresponde à vitalidade da pessoa, sobe aos céus onde vivem os deuses $\mathrm{M}$ aii. Ali, os mortos são primeiro pintados com jenipapo, em um padrão chamado "alma nova". Em seguida, encontram-se com os $M$ aiï, que requisitam presentes (se o morto é uma mulher, querem fazer sexo com ela). Os mortos nunca satisfazem essas requisições. Esse comportamento antiético é punido pelos deuses com a morte (os mortos são inimigos no mundo dos Maii). M ortos e despelados (os Maii conservam a pele como uma espécie de troféu), eles são então fervidos; sua carne é comida por todos os Maii. Seus ossos, todavia, permanecem, e são usados pelo deus Tiwawi para reconstituir-Ihes o corpo, que é depois banhado (ou melhor, cozido) em água efervescente: isso " 'troca a pele' da alma e a revive, tornando-a forte e bela. Uma alma masculina é pintada com jenipapo, em um padrão de linhas finas; a alma feminina tem sua vulva pintada" (Viveiros de Castro 1992:211, ênfases minhas). Todas essas transformações são concomitantes à decomposição do cadáver de um morto. No final, o morto casa-se entre os Maï, estabelecendo com estes relações de amizade formal, apihï-pihã. Dessa maneira, os mortos (como operadores) afinizam os $M$ aii com respeito aos vivos (Viveiros de Castro 1992:202-212).

Essa exegese faz pensar no desembrulho da pessoa fractal discutido no caso do guerreiro tupinambá, embora nos Araweté, como mostra Viveiros de Castro (1992:211-214, 252-272), isso pareça ser posto em termos de uma regressão à natureza e de uma passagem à sobrenatureza. O componente humano-natureza de uma pessoa apodrece e é devorado por espíritos. O componente humano-sobrenatureza é, por sua vez, dividido em um aspecto celeste - o componente araweté - e um aspecto aparentemente inimigo (lembremos que o ta'o we é um ser mortal; inimigos dos A raweté não entram no céu dos Maï, e nesse sentido são apenas tạ'o we [Viveiros de Castro 1992:238]). O aspecto celeste é então separado novamente: a carne (feminina) é comida e os ossos (masculinos) são 
reconstituídos. Se a morte é coisa feminina, seja porque se é comido quanto seja se é uma mulher doada aos Maï, o que permanece - os ossos (futuro M aï) - deve, portanto, ser masculino (o que, aliás, revela a natureza relativa do gênero como uma metáfora do divisor Eu/Outro; volto a isso adiante). Essa separação final é também uma instância da separação da sobrenatureza com respeito à natureza: "só os ossos esquecem", dizem os Araweté, querendo dizer com isso que os mortos, uma vez Ma aï, tendo sido desprovidos de sua carne, sede das emoções e da memória, esquecem os vivos.

A qualidade fractal da pessoa é aqui evidenciada no encaixe de pessoas em partes de pessoas, como representado na Figura 5; é também sugerida pelo uso do termo hiro (que se refere a qualquer contentor) no contexto da morte:

“Hiro, como ĩ, tem um significado posicional. Uma pessoa viva é um hiro em oposição ao espectro [o duplo derivado da sombra]; um espectro é um hiro em oposição a uma imagem i [a vitalidade celeste futuro-Maii], e uma imagem [vitalidade celeste] é um hiro [o morto é comido, ele/a tem carne e osso] em oposição àquilo que não tem forma ou causa, que é subjetivo." (Viveiros de Castro 1992:203)

Relações de morte, inimizade e reprodução são reveladas através da separação dos aspectos constitutivos da pessoa e, como no caso Tupinambá, relações de predação e afinidade são reveladas "em ato" : primeiro, no de ser comido, e em seguida no de casar-se com os Maï. Tudo isso é possível porque os mortos são pessoas divididas, operadores nas relações entre os Maii e os vivos.

\section{Relações com os mortos, relações com os inimigos: questões de escala}

Focalizamos até aqui o processo de desembrulho dos inimigos enquanto operadores em relações. Esta análise oculta o fato de que os matadores, após executarem seus inimigos, são também operadores, pessoas divididas: eles precisam entrar em reclusão, observar restrições alimentares, evitar relações sexuais etc. Em suma, estão em um estado de fragilidade similar àquele dos doentes. As relações entre os Wari' e seus mortos, bem como aquelas entre o matador wari' e seu inimigo, iluminam esse ponto. Voltarei aos casos tupinambá e araweté posteriormente. 
Figura 5: Desembrulhando a pessoa fractal araw eté ${ }^{13}$

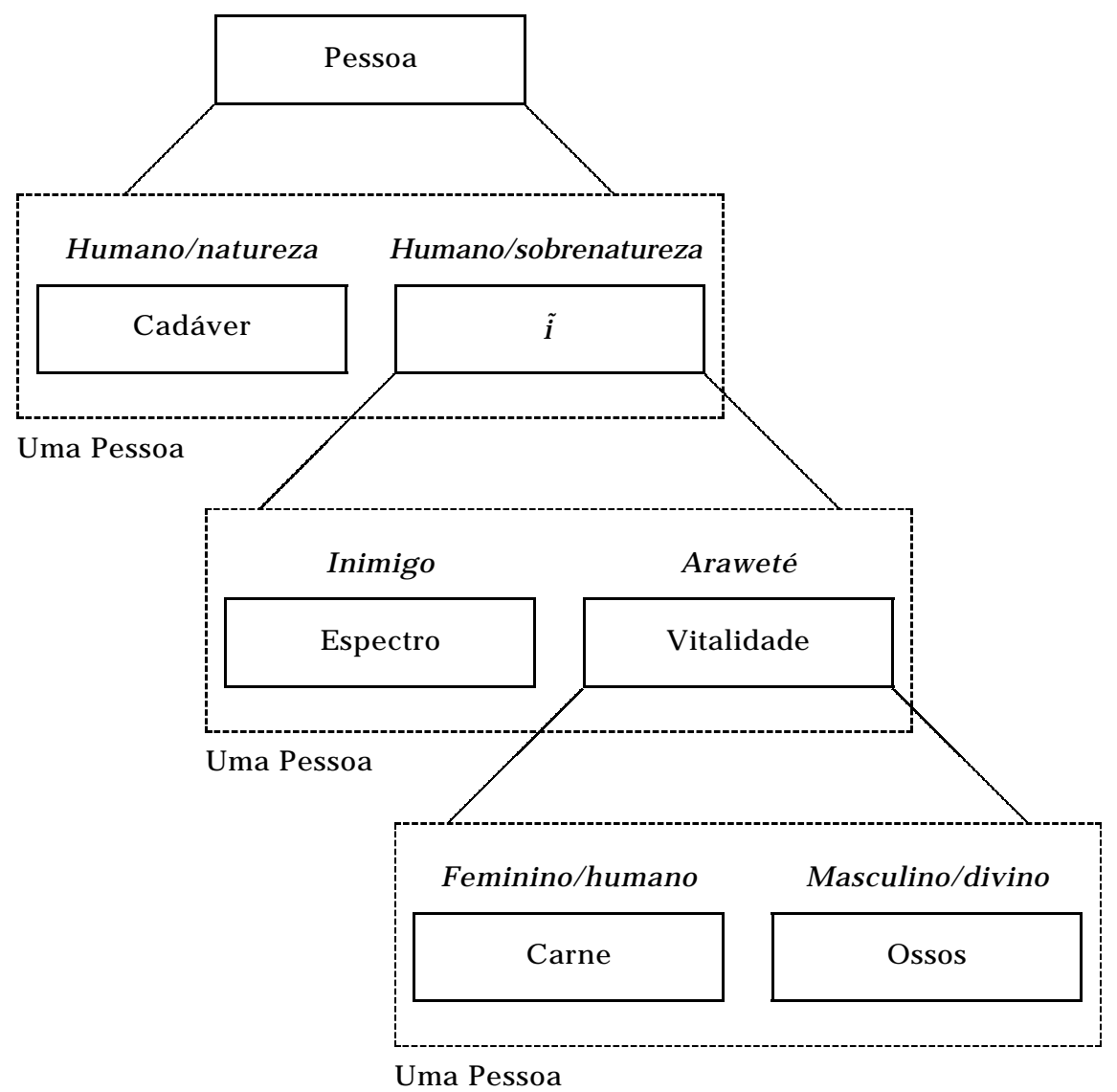

Na escatologia wari', quando uma pessoa está gravemente doente, sua alma viaja para o mundo dos mortos, onde Towira Towira, um homem com testículos enormes, oferece-Ihe chicha azeda. A aceitação, equivalendo simbolicamente ao estabelecimento de uma relação de afinidade com Towira Towira, corresponde à morte definitiva da pessoa. Se esta rejeita a bebida, viverá (Vilaça 1992:250). Um morto recente é referido pelo termo napiri, usado em duas outras situações que permitem estabelecer uma importante conexão simbólica entre mortos recentes, mulheres e matadores. Napiri é uma designação aplicada a jovens moças cujos corpos são vistos como prontos para o casamento: “napiri é a moça pronta 
para efetivar o casamento, a aliança; pronta para receber o sêmen" (Vilaça 1992:104). O termo tem, pois, uma importante dimensão temporal, designando uma pessoa em um período particular: a mulher no momento da troca matrimonial. Nesse sentido, refere-se a uma "mulher doada".

“É interessante lembrar que o morto recém-chegado também é chamado napiri, assim como o matador (e é mesmo associado a ele), o que parece ter relação com seu caráter mediador entre vivos e mortos. Se napiri é 'mulher doada' [...], o morto que chega afiniza os mortos para os Wari'; transformando-os em 'genros' e 'cunhados', torna-os presas, karawa potenciais, que é exatamente como os mortos virão a se constituir para os vivos." (Vilaça 1992:250)

Os mortos reaparecem na terra como queixadas, que tanto podem ser caçados pelos Wari', quanto aparecer como estrangeiros, que vêm dançar nos rituais, ou inimigos. O último ponto que vale mencionar é o modo como, no funeral, os nari paxi, afins e parentes distantes do morto, comem o cadáver como um serviço aos iri'nari que, sendo consubstanciais ${ }^{14}$ do morto, não devem fazê-lo, de modo a evitar o autocanibalismo (Vilaça 1992:209).

As relações vivos/mortos entre os Wari' são mediadas pela troca: o todo (os viventes) dá uma parte (o morto) de si, como pessoas dão partes do corpo. De um lado, há aqui uma relação de afinidade: os mortos recentes wari', chamados napiri, são "mulheres doadas" aos demais mortos, são operadores na relação entre estes e os vivos, definindo os mortos como tomadores de mulheres (termo). E, todavia, os mortos recentes acabam por tornar-se cognatos dos mortos. Essa passagem, que corresponde ao cozimento e consumo na terra do cadáver, é também mediada pela troca com Towira Towira, que simboliza a afinidade. Depois dessa troca, os mortos recentes são banhados e reconstituídos como jovens wari', e reconhecem os demais mortos como seus cognatos. Dessa maneira, eles deixam de ser operadores e tornam-se termos nas relações com os vivos. De outro lado, existe uma relação de predação: os mortos reaparecem no mundo dos vivos como queixadas, que podem ser caçados pelos Wari'. Esses queixadas são operadores nessa relação, definindo os Wari' vivos como predadores (termo). A combinação dessas duas relações estabelece uma clara associação entre predação e coito15. A Figura 6 sintetiza as relações aqui descritas. 
Figura 6: Relações vivos/mortos (operadores em itálico; termos em caixas)

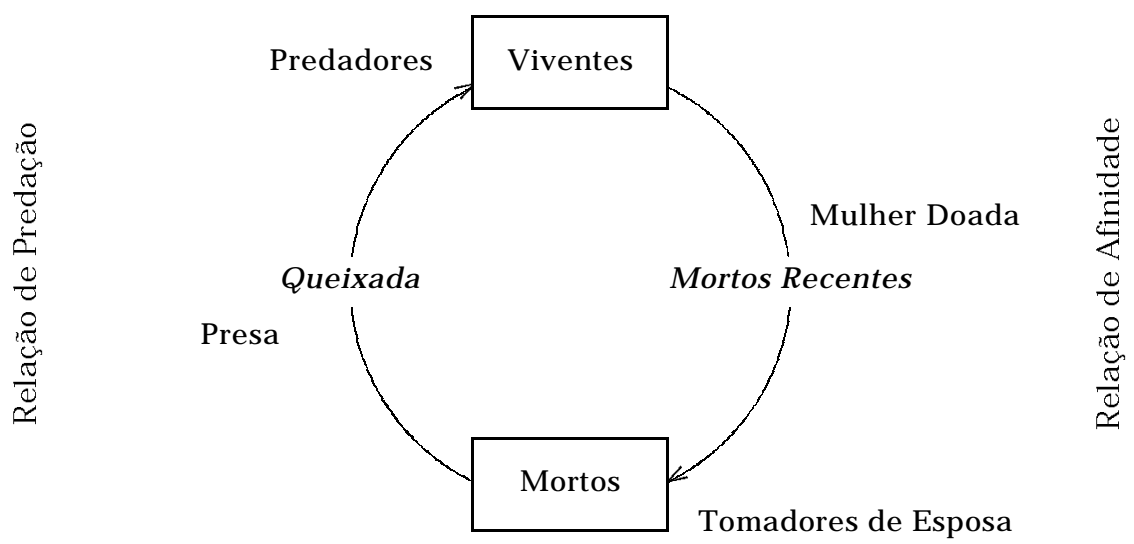

Passemos agora à relação entre os Wari' e seus inimigos. Um matador contém em sua barriga o sangue do inimigo, parte do qual ele transforma em sêmen. Isto é feito durante o período de reclusão ritual que se segue ao homicídio. Do mesmo modo que as moças que alcançaram a maturidade sexual e estão prontas para receber sêmen, os matadores durante a reclusão também são chamados napiri, o que sugere sua associação a mulheres no momento da aliança. Além disso:

“Essa associação [sangue e sêmen] nos permite pensar a penetração do sangue do inimigo no corpo do matador como simbolicamente associada à relação sexual. Efetivamente, depois disso, o matador terá um filho: o yam [alma] do inimigo morto." (Vilaça 1992:103-104)

Depois da reclusão, o matador, que transformou parte do sangue do inimigo em sêmen, pode "engordar" sua esposa (Vilaça 1992:109).

Note-se que aquilo que os mortos fazem aos vivos - afinizá-los - é o que o inimigo faz a seu matador, afinizando-o através de relações sexuais (penetração de sangue), e situando dessa maneira os inimigos e os mortos na posição de Outros: primeiro, o matador é uma mulher doada (como um morto recente); segundo, ele se torna consubstancial com o inimigo (como os mortos recentes reconhecem os mortos como cognatos). É por isso que ele não come a substância do inimigo. Mas o resto dos Wari', estes sim a consomem - o que é precisamente o que os vivos fazem aos 
mortos em forma de queixada. É também o que os afins fazem ao morto, como um serviço para os consubstanciais deste, em um funeral wari'16. A Figura 7 mostra as relações inimigo/matador.

Figura 7: Relações Wari'/inimigos (operadores em itálico, termos em caixas)

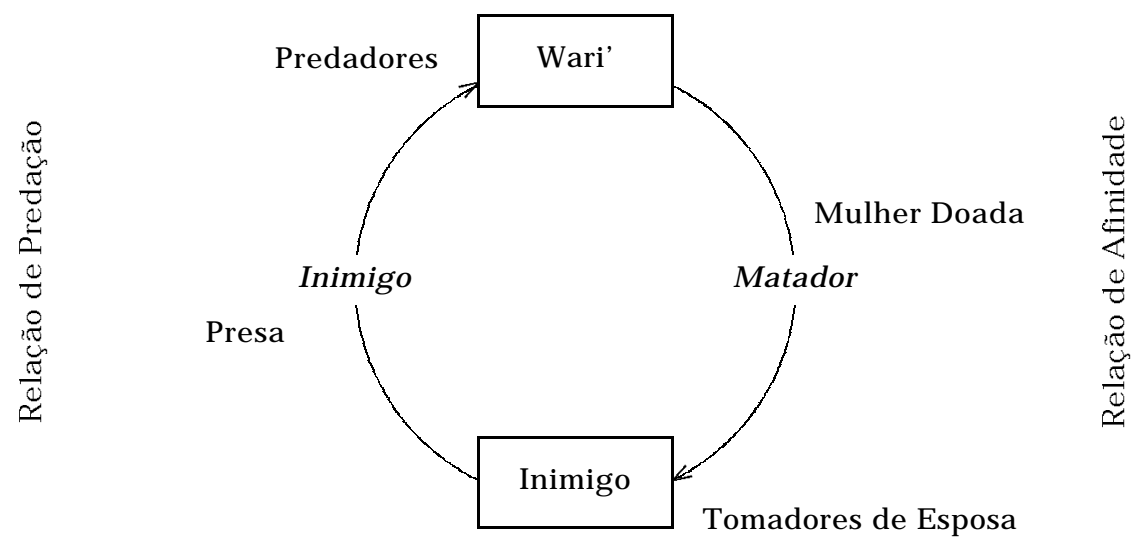

Quando focalizamos o par matador/cativo, é possível visualizar, como no caso tupinambá, o englobamento do Outro pelo Eu. O matador pode não comer da substância do inimigo morto, mas come simbolicamente sua alma transformada em sangue (Vilaça 1992:112). A relação entre os termos é mediada pela troca simbólica de sangue e pela incorporação da alma do inimigo.

Quando nos distanciamos, por assim dizer, e ol hamos para isso a partir de uma escala diferente, notamos que tanto o inimigo cativo quanto o matador são pessoas divididas, operadores nas relações entre as posições genéricas de Wari' e Outro (termos). O inimigo é um operador: sua substância é objeto de predação e, portanto, de devoração. O matador é um operador: consubstancial com o inimigo, é posto em reclusão, precisa repousar e digerir o sangue da vítima, e está em uma relação especial com o resto do grupo. Essa identificação leva a pensar no inimigo morto e no matador recluso como, simultaneamente, divididos e fundidos: juntos, constituem uma pessoa. N esse ponto, a noção de $M$. Strathern de "divíduos", como foi visto para os Tupinambá, ganha uma utilidade mais 
explícita: “uma dualidade interna é externalizada ou elicitada na presença de um parceiro: o que era 'metade' de uma pessoa se torna 'um' de um par" (Strathern 1988:15). O matador, na posição de uma mulher doada, é análogo à alma de um morto (lembremos que ambos são chamados napiri), quer dizer, ele equivale à "metade" da pessoa que vai para o outro mundo. $O$ inimigo, como presa, segue o caminho do cadáver de um morto, a "metade" da pessoa que é comida pelos afins (Figura 8).

Figura 8: A dividualidade wari' durante a reclusão do matador ${ }^{17}$

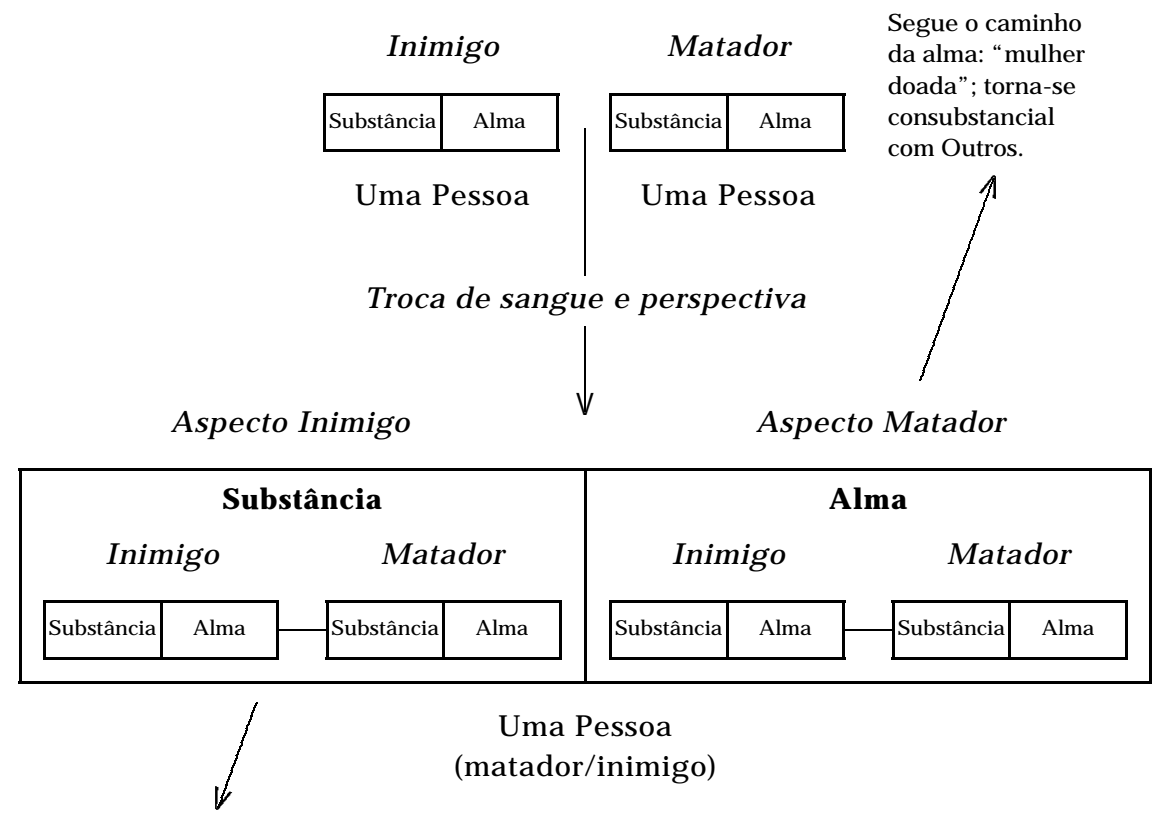

Segue o caminho do cadáver: devorado por Outros

Dado que o cadáver do inimigo acaba por desaparecer, pode-se dizer que, depois disso e antes do levantamento da reclusão (que dura cerca de um mês), o matador é "metade" de uma pessoa; como veremos adiante, um processo de modificação corporal o faz completo mais uma vez. A Figura 9 resume as relações vivos/mortos e aquelas entre inimigos, mostrando como estas se espelham mutuamente. 
Figura 9: Relações vivos/mortos e entre inimigos

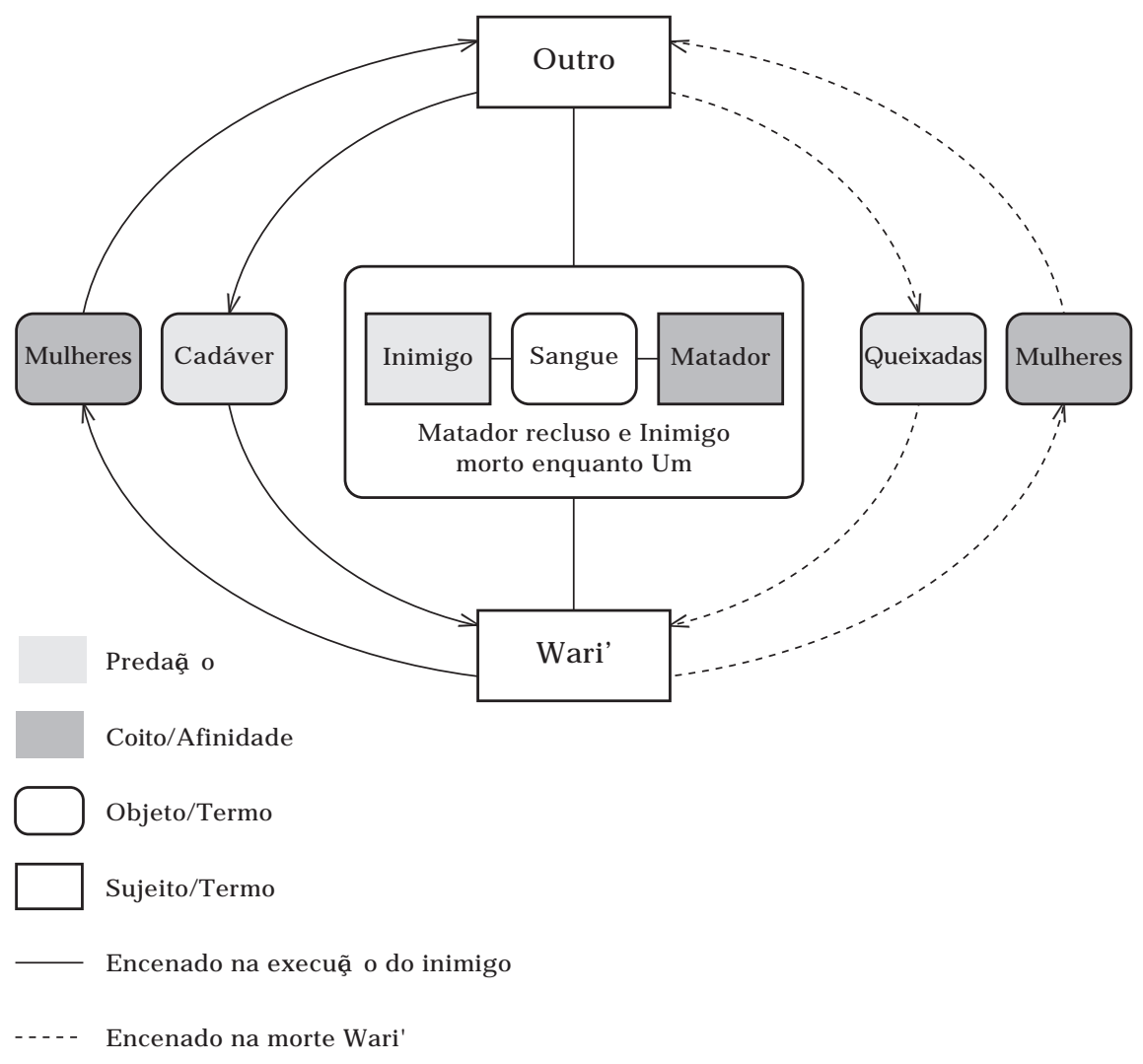

A mesma lógica parece estar operando no caso tupinambá. Um todo (o grupo inimigo) dá uma parte (o cativo) que significa relações de afinidade e inimizade entre dois grupos inimigos (termos). U ma replicação dessa relação ocorre quando o cativo (todo, termo) dá seu sangue (parte, operador) a seu matador - um momento em que, juntos, eles vêm significar relações de predação, morte e reprodução (Figura 10).

A diferença do caso tupinambá está em que ali não há relações com os mortos, apenas trocas recíprocas entre inimigos. M as mesmo se os inimigos subsumem relações distintas com respeito ao caso wari', eles marcam ao mesmo tempo a separação entre dois tipos de relação: entre matador e cativo e entre grupos. Isso é evidenciado pela ressubjetivação do cativo no momento em que ele está na iminência de ser morto. Os inimi- 
Figura 10: Relações entre inimigos tupinambá

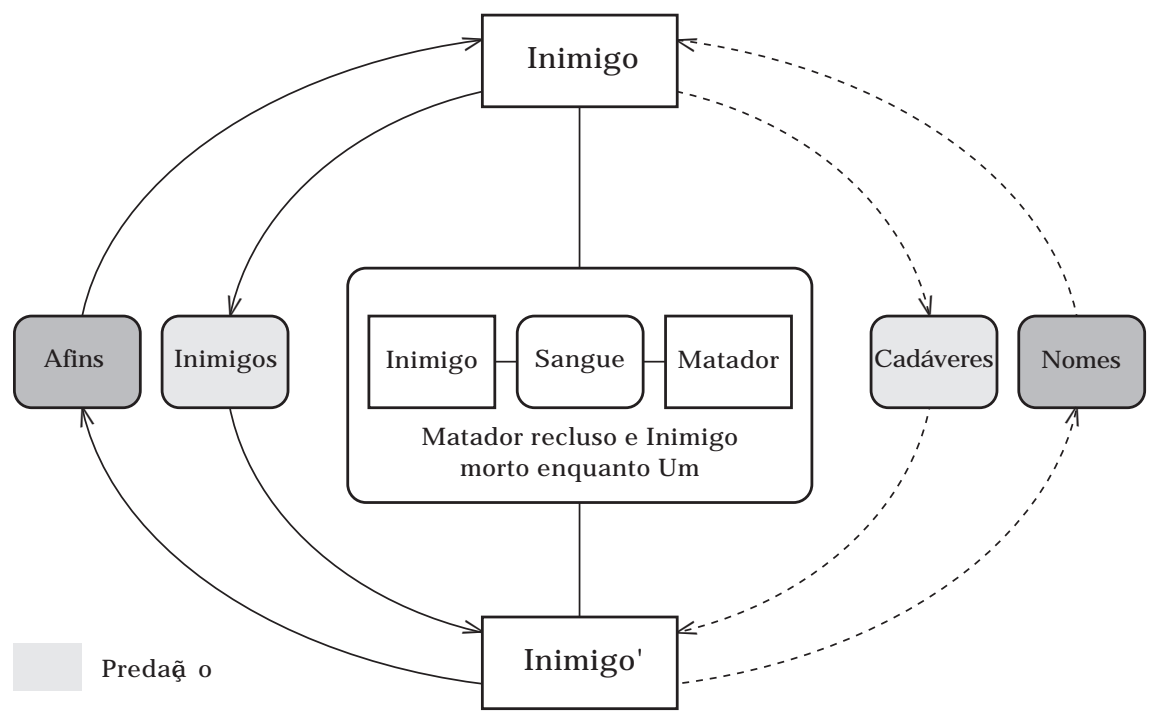

A finidade/M orte/Reproduẹ̃ o

Objeto/Termo

Sujeito/Termo

Encenado nas relaọ̃ es com os inimigos

Encenado nas relaọ̃ es matador/cativo

gos como grupos são o paralelo dos mortos wari', e é nessa escala que o par tupinambá matador/cativo é um operador entre o grupo do matador e o grupo do inimigo (termos).

Se, no caso wari', os mortos fazem com os vivos o que os inimigos fazem com os Wari', associando inimigos e mortos na posição comum de Outros, aqui os inimigos fazem uns aos outros o que eles fazem uns aos outros, por assim dizer. A relação recíproca entre inimigos leva a uma situação algo paradoxal de associação de Outros a N ós, e é somente através do deslocamento temporal que a equação $\mathrm{Eu}=\mathrm{I}$ nimigo pode ser sustentada (Viveiros de Castro [1992:291-292] está certamente correto em sublinhar a produção do tempo no contexto da execução ritual do cativo). 
Isso nos leva a discutir o caso final dos Araweté. Aqui os guerreiros geralmente retornavam com uma parte do corpo do inimigo morto, um úmero ou escápula conservados como troféus, da mesma maneira que os deuses $\mathrm{M}$ aï conservam a pele dos mortos. O matador efetivo, como sua contraparte tupinambá, retira-se e submete-se a uma série de interdições, absorvendo o sangue de sua vítima e espelhando a morte dela com a sua própria. Isso marca o princípio de uma nova relação com o inimigo; em vida, o matador e a alma da vítima tornam-se apihï-pi hã, amigos formais, e o inimigo dá cantos e nomes para que o matador os transmita; na morte, os dois participantes dessa relação se fundem na constituição de um único Maii (Viveiros de Castro 1992:239-245). Como nos exemplos wari' e tupinambá, o par matador/inimigo reúne as duas facetas da pessoa, explicitamente reveladas na morte. O matador segue uma trajetória paralela à do aspecto vital do morto, do î: ele morre ritualmente e ressuscita para entrar em relações de apihï-pihã com o inimigo (assim como um Araweté comum morre e entra no final em uma relação de apihï-pihã com os Maï). O inimigo segue o caminho do cadáver de um morto: ele apodrece na floresta (presumivelmente liberando um tá'o we, um espectro). Eles são um e o mesmo, a alma-sangue do inimigo foi incorporada, o que faz de ambos Outros dos A raweté.

Os A raweté apresentam uma outra variante da lógica apresentada, na qual se pode ver uma combinação de traços tupinambá e wari'. De um lado, como entre os Wari', podemos aqui distinguir relações com inimigos daquelas com os deuses Maï. De outro lado, os deuses Maii fazem aos vivos o que os A raweté fazem a seus inimigos ${ }^{18}$, associando os $\mathrm{M}$ aii aos A raweté enquanto "Nós". Mas isso leva à contradição notada para os Tupinambá: os Maï comem os mortos recentes, eles são inimigos, mas ao mesmo tempo tomamos seu lugar entre os vivos. Os A raweté são o equival ente terreno do Maï, o Inimigo: apenas o tempo (a morte) é capaz de sustentar a equação Eu = Inimigo. Outra diferença importante é que enquanto os Tupinambá e os Wari' relacionam-se com os inimigos reciprocamente, a relação dos Araweté com os Maii não é recíproca, os Maii são destino: destino final.

\section{Troca de perspectivas}

Enfrentemos agora uma importante questão: se inimigo e matador trocam perspectivas, como as pessoas conseguem viver com inimigos dentro? Se o matador se torna o inimigo, como ele pode ser "Nós"? Retornemos aos Wari'. 
Um matador é posto em reclusão, uma "meia"-pessoa, dividida: ele é consubstancial com o Outro (inimigo morto). A retotalização da pessoa do matador após a reclusão envolve a assunção, pelo inimigo dentro, de uma perspectiva wari'. Isso é feito cuidadosamente através do banho e da pintura a que se submete o matador. Depois disso, o sangue de seu inimigo o fertiliza: o inimigo torna-se um filho do matador, e este pode agora reassumir relações sexuais com sua esposa. Mas isso é uma inversão do ponto de vista do inimigo: o filho do matador é a alma do inimigo; através da pintura e do banho (modificações corporais), porém, faz-se com que ele veja os Wari' (inimigos) como “Nós" (ex-inimigos). Esse estágio tem seu paralelo no banho a que é submetido o morto ao chegar no outro mundo, após o que este reconhece os demais mortos como cognatos. Estando-se morto, "Nós" (wari') é uma posição dos mortos. O que explica como os elementos do par matador/inimigo são objetos temporários (operadores) de outra subjetividade: um é o objeto dos Wari' enquanto mortos (uma mulher doada), o outro é objeto dos Wari' enquanto vivos (presa, comida). M odificações corporais, pois, completam uma pessoa dividida. Uma "metade" torna-se um todo com uma dualidade interna Eu/Outro. Na medida em que a qualidade-de-sujeito é recuperada, ela pode ser invertida (um matador pode matar de novo ou se tornar presa, os mortos podem ser caçados pelos vivos Wari'), e o que é reconstituído é uma pessoa.

Aqui, o papel da troca e do banho-pintura é crucial: primeiro, na troca, um inimigo se torna um Wari'; segundo, no banho-pintura (do matador após a reclusão e dos mortos recentes depois da troca com Towira Towira), os inimigos (Wari'/mortos) são reconhecidos como "N ós" (exinimigos) (Figura 11).

Isso corresponde ao tratamento do cadáver que é primeiro assado e depois comido; também ratifica o fato de que toda troca de perspectiva é uma modificação/transação corporal19.

Uma situação similar pode ser encontrada no tratamento tupinambá do cativo antes do ritual de homicídio. Em um certo sentido, identificando-se com a posição de seu executor (falando como um predador, sendo decorado etc.) ele está fazendo do Outro e seu grupo um "Nós". Mais que isso, uma vez capturado, o cativo era considerado em sua própria aldeia um homem morto, que não seria aceito de volta se retornasse aos seus, para que os captores não imaginassem que esses não podiam vingá-lo (Viveiros de Castro 1992:287). Assim, para o cativo, "Nós" era o grupo de seu captor, devido tanto à sua identificação com seu matador, à sua qualidade-de-matador [killer-ness], quanto à sua não-identificação com seu 
Figura 11: Paralelos entre matar e morrer para os Wari'

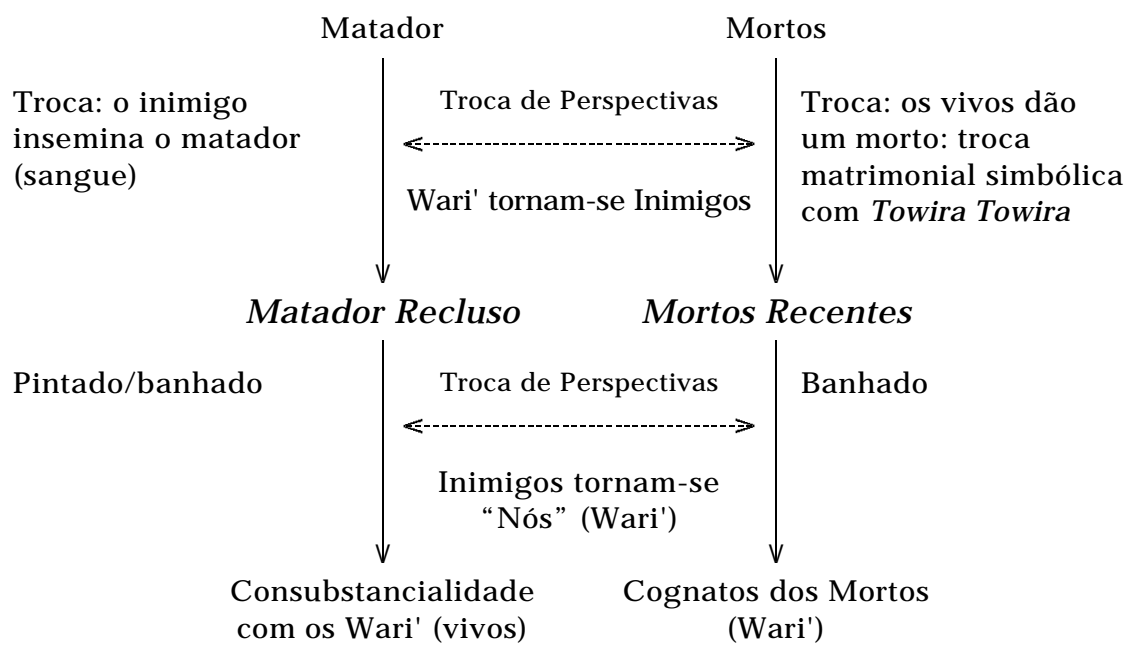

grupo, sua qualidade-de-morto [dead-ness]. “Nós” não pode ser senão o Outro de outros.

O par troca/modificação corporal também pode ser visto em operação entre os Tupinambá, mas aqui a escatologia se situa nas relações entre grupos inimigos. Primeiro, por meio de uma troca (cativo/sangue), um inimigo torna-se parte do grupo do captor ou o próprio captor; segundo, por meio de modificações corporais (ressubjetivação do cativo, nomes novos), um inimigo (cativo, matador recluso) torna-se "Nós" (Figura 12).

$\mathrm{O}$ caso dos Araweté é mais complexo. Dada sua relação não-recíproca com os deuses $M$ aiï, o matador araweté, ao adquirir seus traços divinos, nunca deixa realmente de ser um Maï, um Outro entre seus conterrâneos. $A$ relação com os $M$ aï é mais de atração que de troca recíproca, os Maii não são pessoas (como os mortos Wari'), são deuses; ninguém come os Maî. Ao se tornar Maiï, o matador nunca mais recupera sua qualidade-de-pessoa [person-ness].

O matador toma o ponto de vista do inimigo de duas maneiras: de um lado, ele espelha a morte de sua vítima; de outro, ele ressuscita como um Maï na terra. Os A raweté têm dois tipos de Outro: os inimigos viventes e os Maï canibais. O matador é ambos. Ele entra em reclusão e observa interdições (como fazem pessoas divididas), mas seu corpo não é depois modificado, seja por pinturas ou novos nomes. O segundo passo que veri- 
Figura 12: Paralelos entre o homicídio tupinambá e trocas com inimigos

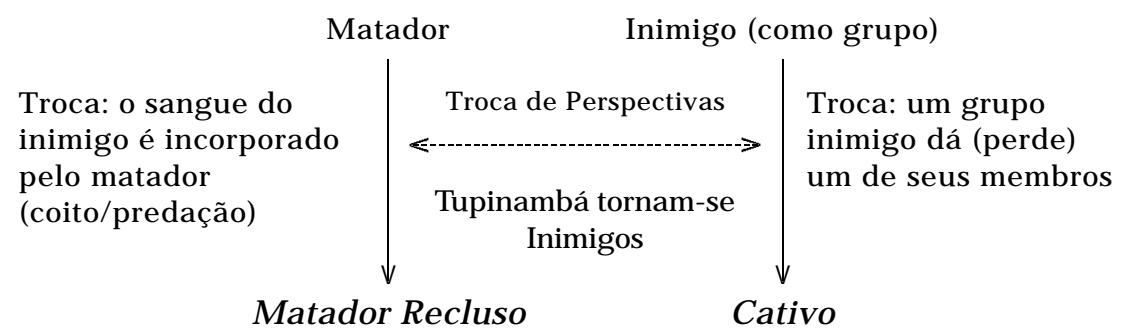

\begin{tabular}{l|l|l}
$\begin{array}{l}\text { Modificação corporal: } \begin{array}{l}\text { o matador adquire } \\
\text { novos nomes }\end{array} \\
\text { Afim/Inimigo }\end{array}$ & $\begin{array}{l}\text { Troca de Perspectivas } \\
\text { Inimigos tornam-se } \\
\text { "Nós" }\end{array}$ & $\begin{array}{l}\text { ressubjetivação corporal: } \\
\text { do cativo antes } \\
\text { da execução }\end{array}$ \\
(Reprodução social) & $\begin{array}{l}\text { Inimigo' (como grupo) } \\
\text { (Imortalidade) }\end{array}$
\end{tabular}

ficamos para os Wari' e para os Tupinambá não ocorre nesse caso. Diversos fatos indicam sua qualidade-de-inimigo [enemy-ness]: 1) o matador araweté transmite os nomes que a alma de seu inimigo lhe dá, mas não os "veste" ele mesmo; 2 ) ele não pode reassumir relações sexuais com sua esposa até muito tempo depois do homicídio, pois do contrário seria seu inimigo quem faria primeiro sexo com sua esposa; 3) suas armas precisam ser mantidas longe dele no período pós-homicídio, para evitar que o inimigo se vingue nos conterrâneos do matador; 4) nos cantos que o matador canta, é o inimigo que ocupa a posição de sujeito; 5) mais importante, o matador é a única pessoa poupada, na morte, da antropofagia divina, passando diretamente ao banho reconstitutivo (modificação corporal). O matador tampouco libera um espectro (alguns dizem que o faz, mas apenas um inofensivo).

O matador libertou-se assim de seu ta'o we, seu espectro, o qual se encontra "encorporado" [embodied] no cadáver putrescente do inimigo. Está aqui em questão tanto a conversão do matador em Maiï, em um inimigo, quanto a incorporação do inimigo ao matador. Inimigos são puro tá'o we 20 - ao se tornarem um sujeito com seu executor eles se tornam í, e deuses $M$ aï na terra. Todavia, na medida em que nenhuma modificação corporal completa a pessoa do matador, ele permanece dividido, o único indivíduo: “Este é o paradoxo do guerreiro Araweté: puro espírito, 
homem sem sombra e sem carne, ele é seu próprio inimigo, e o centro de uma sociedade sem centro." (Viveiros de Castro 1992:251, ênfases minhas)

Se o matador é um Maiï, então sua posição de sujeito não pode ser revertida. Evidência disso é a idéia de que em tempos passados, os matadores nunca morriam, mas subiam aos céus em carne e osso (Viveiros de Castro 1992:246) - eles não podem ser feitos presa. Enquanto os nãomatadores araweté realizam a equação $E u=$ Inimigo através do tempo, morrendo, passando de "Nós" na terra (Araweté) a "Nós" nos céus (Maii), um matador anula o tempo com sua morte ritual e, assim, se torna Eu e Inimigo na terra, encorporando a posição ambígua dos Mäï, que primeiro nos comem, mas em seguida são o "Nós" no céu. $O$ ponto é que um processo que tem início na terra, com o homicídio e a conversão em inimigo (passo 1), é completado apenas no céu, por meio da mudança de corpo no banho restaurador (passo 2). M as essa assimetria com respeito ao processo sofrido por todos os outros Araweté significa que o matador nunca deixa de ser um Outro, nem mesmo no mundo dos Maii. Aqui, ele é um Iraparadï, um ser temido pelos deuses.

“Ao designar o estatuto do matador araweté, o conceito de I raparadï revelase como sendo essencialmente uma perspectiva: se os Maï são ao mesmo tempo o correspondente celeste dos Araweté e uma figuração do Inimigo, se eles nos olham com olhos de inimigo, e se os olhamos como inimigos, os Iraparadï são os Araweté se pensando ativamente como inimigos. Eles são algo que os Maï temem, assim como os mortos comuns temem os Maï." (Viveiros de Castro 1992:248-249)

O matador é um Outro na terra em virtude da troca com o inimigo, e um Outro dos Maii em virtude de uma modificação corporal21. A diferença com os outros casos é que, aqui, o primeiro passo do processo se dá quando o "Nós" são os Araweté vivos, e o segundo passo ocorre quando o "Nós" são os Maii. Assim, em lugar de inimigos (mortos recentes) se tornarem “Nós" (Maii), é o “Nós" (Maï) que se torna inimigo (dos Iraparadï) (Figura 13).

\section{Veículos de perspectiva}

Até aqui, detivemo-nos na maneira como relações entre grupos (inimigos, mortos) são replicadas entre indivíduos. No primeiro caso, os opera- 
Figura 13: Paralelos entre morrer e matar nos Araw eté

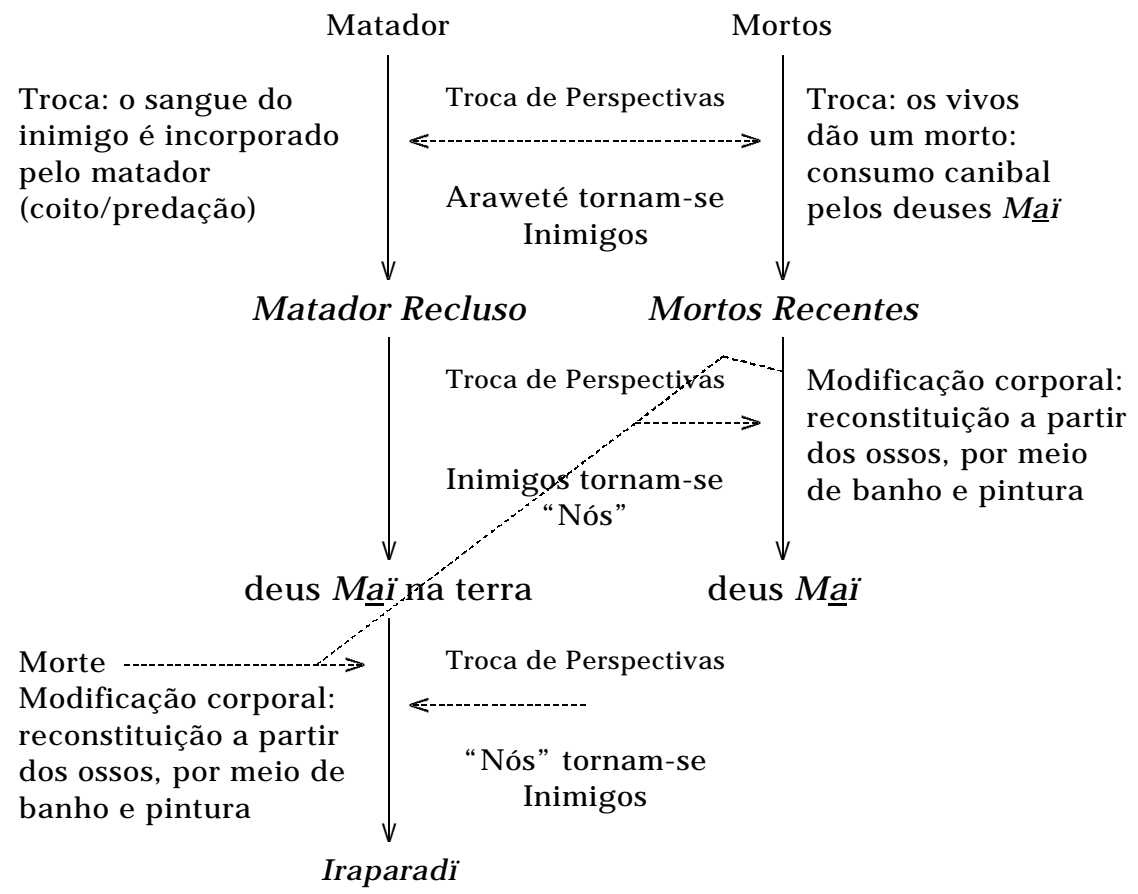

dores são pessoas (cativos, mortos recentes); no segundo, partes de pessoas (sangue) servem como tal. M as se o sangue pode ser um operador, é apenas porque é capaz de significar relações, e deve assim poder ser Outro em uma ocasião e Eu em uma outra. O sangue é um fractal em escala reduzida da pessoa.

No caso wari', a transformação do sangue (do inimigo) em sêmen (do matador) é uma instância justamente disso. Para os Araweté é o aspecto vital, o i de uma pessoa, que se torna um deus Maii ("Nós" no outro mundo). Para os Tupinambá podemos sugerir uma associação entre sangue (do inimigo) e nomes (do matador). Em todos os casos, uma parte de um Outro se torna um Eu, a afinidade é transformada em consubstancialidade. É porque partes de pessoas (o sangue, o ĩ araweté) participam da fractalidade da pessoa que esta se constitui como dual e pode assumir posições opostas, adotar diferentes perspectivas. Contendo partes transformáveis e transacionáveis, as pessoas são elas próprias duais, transformáveis e transacionáveis. 
Se focalizamos as transações de sangue, podemos discernir a alternância de posições, a reversibilidade das pessoas. A transação de sangue wari' põe em primeiro plano a dualidade masculino/feminino das pessoas: o matador (masculino) é primeiro inseminado e fertilizado (feminino); depois do banho e da pintura, ele será um inseminador (masculino) de sua esposa, a quem “engorda” (Figura 14).

Figura 14: A posição do matador w ari' no homicídio ritual

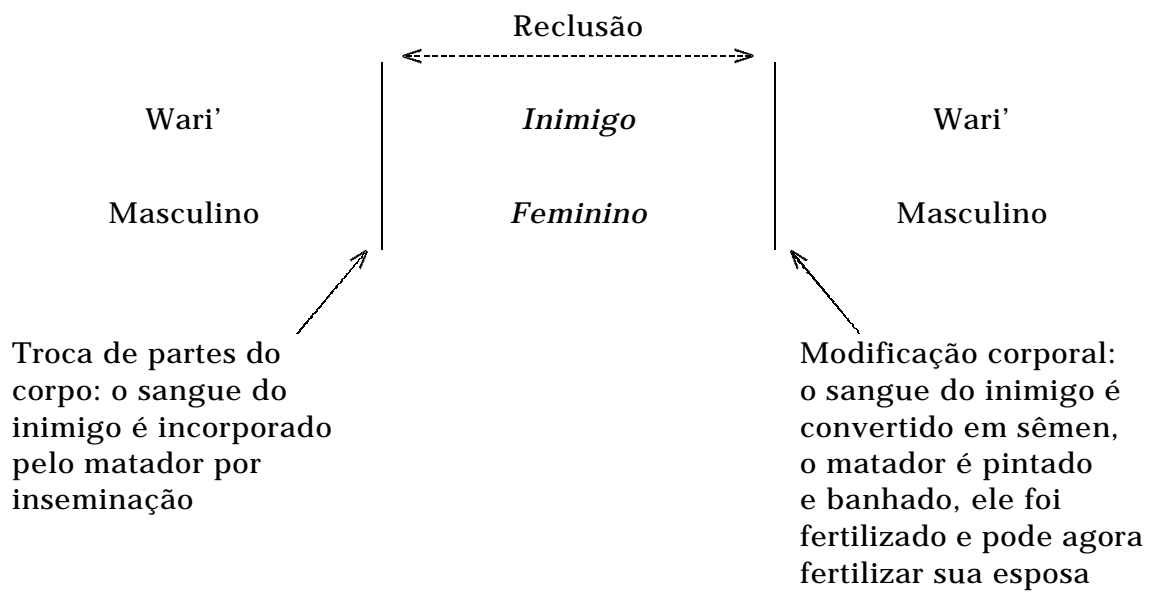

Podemos ver, no caso dos Tupinambá, um processo similar: 1) o sangue inimigo penetra o matador; 2 ) o corpo do matador é modificado por novos nomes e ornamentos (sangue transformado), após o que ele pode casar-se e ter filhos (Figura 15).

Para os Araweté, constata-se que os vivos, quando morrem, são primeiro consumidos (femininos) e depois desposados pelos Maï (Figura 16). 
Figura 15: A posição do matador tupinambá no homicídio ritual (no caso da iniciação de um rapaz)

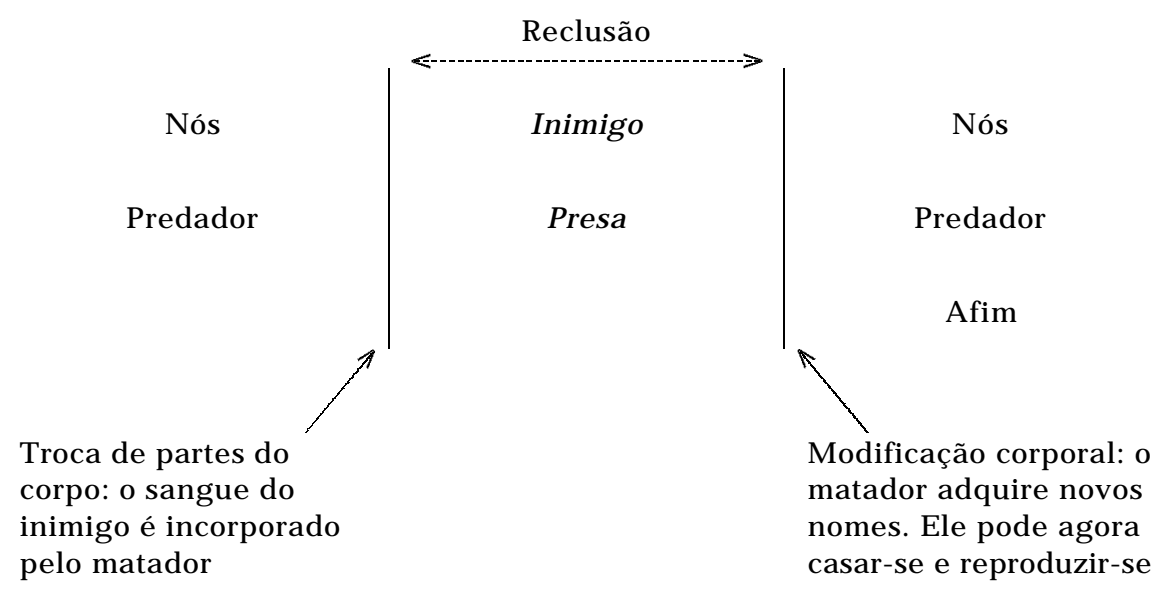

Figura 16: Posições no processo da morte nos Araw eté

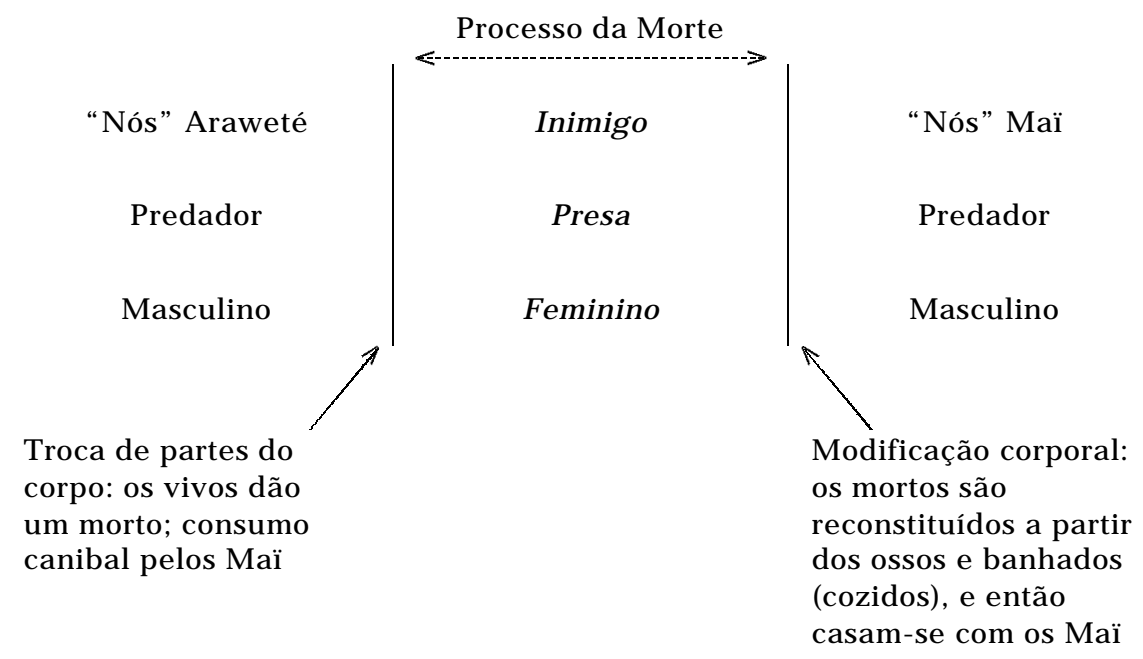




\section{Conclusão}

A fractalidade da pessoa revela-se através do desembrulho das relações que a constituem. Esse processo revela uma similaridade auto-escalar. $O$ englobamento do Outro pelo Eu é a conclusão dessa trajetória: inimigos tornam-se Nós, viventes tornam-se os mortos. O processo envolve a troca de partes do corpo e modificações corporais: no primeiro caso, Outros (inimigos) se tornam Eus (matadores); no segundo, Outros são redefinidos como Nós. O primeiro é uma troca de lugares no interior de uma mesma moldura - você se torna eu e vice-versa; o segundo é uma mudança de molduras - você verá o mundo como eu o via antes da troca. O primeiro implica o multinaturalismo, o segundo a humanidade da posição reflexiva de sujeito. Esses dois passos constituem a essência do perspectivismo: 1) englobamento (predação/intercurso sexual) via transações que fazem de Outros versões do Nós; 2) o corpo, como sede de perspectivas, é modificado, fazendo Outros verem o mundo como Nós, quer dizer, como exOutros. O "Nós" sempre tem a última palavra, pois se trata de carregar a qualidade de sujeito consigo. Se o corpo é sede de perspectivas, então suas partes transacionadas, real ou imaginariamente, são veículos de perspectiva. O perspectivismo é, literalmente, uma troca de perspectivas, algumas vezes mediada pela troca de partes do corpo, isto é, partes da sede-de-perspectiva. Essas partes contêm pessoas inteiras: o sangue está para a pessoa assim como a pessoa está para o grupo, todos são uma "pessoa fractal".

A análise do modo como as relações com os mortos e as relações com os inimigos são articuladas, acoplada à idéia da pessoa fractal, mostra-se como uma heurística útil para a comparação. Revelaram-se dessa maneira os papéis cruciais da troca e das modificações corporais, assim como as diferenças entre relações recíprocas (Wari') e não-recíprocas, ou de relações "de atração" [atractor relationships] (particularmente evidentes no exemplo araweté, embora também presentes no caso dos Tupinambá)22. Estes últimos, por sua vez, sublinham que, embora existam apenas duas posições possíveis nas relações baseadas na identidade, na oposição Eu/Outro, a base desse sistema é uma tríade: transator $A$, coisa transacionada e transator $B$. Em um plano, os que transacionam são diferenciados do que é transacionado (ver Strathern 1988:177); em outro, A (doador de esposa/vivo/inimigo) é diferenciado de B (tomador de esposa/morto/nós) como a história é diferenciada do destino. Aqui o tempo e a morte desempenham o papel diferenciador.

Quanto a teorias, este ensaio sugere uma proximidade teórica entre a antropologia melanésia e amazônica, sublinhando a importância de cer- 
tas transações para a sustentação de uma ontologia perspectivista23, um aspecto talvez pouco enfatizado na teoria do perspectivismo24, mas que é o feijão-com-arroz da antropologia melanésia. Isso não significa dizer que as situações melanésia e amazônica sejam idênticas: elas não o são. Este não é o lugar para uma comparação plenamente desenvolvida; é suficiente dizer que os paralelos com a troca de dons melanésia parecem ter mais a ver com a "troca" que com o "dom". Uma importante diferença, pelo menos, reside no fato de que trocas predatórias culminam com uma fusão de identidades distintas; o Outro é englobado pelo Eu, enquanto a troca de dons mantém as distintas identidades dos parceiros mesmo quando um pode ser visto como metáfora do outro25. Todavia, algumas idéias na direção de uma visão da pessoa centrada na troca [exchange view] constituem possivelmente uma entrada teórica capaz de servir como ligação para analisar grupos caracterizados mais pelo comércio que pela guerra.

Recebido em 17/12/99

A provado em 20/4/01

Tradução: Marcela Coelho de Souza

Revisão Técnica: A parecida Vilaça

J osé A ntonio Kelly Luciani é formado em engenharia el etrônica pela Universidad Simón Bolívar, Caracas, Venezuela, e fez o mestrado em Antropologia Social na University of Cambridge, Cambridge, UK. Hoje doutorando na mesma instituição, desenvolve pesquisa na região do Alto Orinoco, Venezuela. 


\section{Notas}

* Gostaria de agradecer a Eduardo Viveiros de Castro pela leitura de versões anteriores deste artigo e por seus comentários encorajadores; a A parecida Vilaça, por suas observações e revisão do material wari'; e, finalmente, a Stephen HughJ ones, que me conduziu a esses temas e leu vários rascunhos deste trabalho.

1 Há, certamente, muito mais na teoria dos fractais do que a auto-similaridade escalar. O que estou tomando emprestado da matemática é a imagem de figuras que apresentam a mesma forma em diferentes escalas. Outros aspectos matemáticos importantes dos fractais são sua dimensionalidade fracionária e o fato de que podem aparecer como atratores em sistemas caóticos. M esmo imaginando que esses aspectos possam gerar interessantes reflexões antropológicas, não me detenho em tais temas neste ensaio.

2 M inha dívida intelectual para com Eduardo Viveiros de Castro e Marilyn Strathern não poderia ser exagerada. Preciso também destacar os "Strathernograms" de Alfred Gell (1999), trabalho que foi muito valioso para me auxiliar na compreensão da contribuição teórica de ambos os antropólogos. A marca desses três autores é muito explícita em meu texto. M. Strathern (1988; 1992) e Viveiros de Castro (1992; 1998) constituem as duas principais fontes teóricas deste ensaio. Gostaria, além disso, de enfatizar que não pretendo ter entendido perfeitamente as complexas teorias mobilizadas por esses autores; este trabalho se baseia pois em uma compreensão na melhor das hipóteses parcial.

3 O presente etnográfico é empregado nas descrições dos Wari', embora estes não mais pratiquem o canibalismo funerário ou guerreiro. O mesmo é feito quanto aos A raweté, no que toca à ritualização da guerra (Viveiros de Castro menciona alguns episódios violentos com os Parakanã no início dos anos 80 , mas não tenho informações relativas ao seu presente envolvimento em qualquer tipo de atividade guerreira). Esse uso foi escolhido para salientar o contraste com o material tupinambá do século XVI.

4 Vilaça está, de certa maneira, sugerindo exatamente isso: “[...] é necessário lembrar que wari' e karawa são posições reversíveis e que essa reversibilidade é produzida justamente no ato de devoração canibal, que simultaneamente as constitui como categorias distintas. A posição de presa está contida naquela de predador, e vice-versa, o que certamente tem relação com o fato de os Wari' classificarem suas presas preferidas como predadores potenciais." (Vilaça 1992:291)

5 Isso não é exatamente assim; seria mais correto dizer que os deuses são quase sujeitos puros. $\mathrm{O}$ caso dos deuses araweté (discutido mais adiante) mostra como a posição de sujeito pode ser "desafiada" mesmo ali onde eles não são nunca objeto de troca ou devoração. 
6 Isso não quer dizer que "uma parte da pessoa" no contexto melanésio seja equivalente à alma ou a qualquer outro aspecto da pessoa ameríndia. A equivalência que quero estabelecer não diz respeito ao que pode ser anexado ou desanexado, mas, precisamente, à possibilidade de separar aspectos da pessoa. É a propriedade comum da divisibilidade que estou sugerindo. Mais do que isso, é apenas em certos contextos que aspectos da pessoa que seriam de outro modo fundidos ou indistinguíveis, tornam-se distinguíveis, desintegrados da pessoa plena e assim separáveis dela (nos exemplos abaixo podemos ver como a morte desintegra a pessoa em partes ou aspectos que na vida são ou inseparáveis ou indistinguíveis).

7 Meu uso dos termos "operador" e "termo", que acho cômodos, vem de Gell (1999).

8 Essa técnica de "desembrulho" ["unpacking"] de relações, que considero iluminadora, é tomada de Gell (1999), que a chama "detotalização da personitude fractal". Prefiro "desembrulho" apenas em nome da economia vocabular.

9 A cor cinza indica que, nesse estágio do processo de desembrulho, o inimigo cativo é mais uma vez tornado sujeito, e seu sangue converte-se em um operador na relação entre ele e o matador.

10 À exceção da posição de sogro. Posso propor duas razões para isso: 1) trata-se de uma posição que envolve poder demais para ser, mesmo simbolicamente, atribuída a um cativo; 2 ) segundo Viveiros de Castro, o jogo de afinização do cativo parece ter sido uma paródia da posição dos jovens em suas aldeias. Se os jovens maridos são "prisioneiros" de seus afins, vivendo uxorilocalmente e submetidos aos caprichos de seus sogros, o inimigo cativo apresenta-se como um caso extremo dessa subordinação do jovem a seus afins (Viveiros de Castro 1992:298). Se este é o caso, um cativo nunca tomará a posição de sogro.

11 Tampouco o faz o matador wari', pois o matador é consubstancial com o inimigo morto: “É evidente que a penetração desse sangue exógeno promove, antes de tudo, a consubstancialidade entre o inimigo e o matador [...]. Assim, a ingestão pelo matador da carne do inimigo morto seria autocanibalismo, o que o levaria à morte [...]" (Vilaça 1992:103).

12 Em primeiro lugar, é preciso lembrar que esse exemplo supõe o caso de uma iniciação. Segundo, embora trocas entre os Tupinambá e seus inimigos fossem postas mais em termos de aquisição de nomes que em termos de reprodução, alguns estágios no ritual final associavam, aparentemente, o homicídio e a função reprodutiva das mulheres. Carlos Fausto nota que, embora houvesse uma relação entre o homicídio e a capacidade reprodutiva, aquele não era uma condição para esta última. Deixo aqui para os especialistas tupi julgarem o grau de especulação nessa instância de meu argumento.

13 Esse quadro e minha descrição contam, na verdade, apenas metade da história escatológica da decomposição da pessoa. As partes "deixadas para trás", 
por assim dizer, também sofrem suas próprias decomposições: por exemplo, é o ĩ do corpo putrescente que será canibalizado pelos espíritos, enquanto sua substância é "comida" pela terra. Para simplificar, deixei isso de lado, já que nada aí invalida meu argumento.

${ }^{14} \mathrm{~A}$ partilha de substâncias entre os Wari' é formulada em termos da mistura de sangue e da comensalidade, de partilha de um mesmo corpo por pais, filhos e esposos (Vilaça 1992:34, 52-53).

15 Consideremos o que diz Viveiros de Castro: “[... ] se não se trocarem matrimonialmente pessoas, então isso será efetuado pela reciprocidade canibal. A ausência de casamento ou um fluxo unidirecional de pessoas (mulheres) abrem um crédito canibal, recíproco ou unidirecional (na direção inversa)." (apud Vilaça 1992:293)

$16 \mathrm{~N}$ ote-se que esses dois eventos que envolvem comer estão encenando as relações mortos = afins = inimigos, pois são os afins que comem o morto wari', da mesma maneira que todos os Wari' de uma aldeia comem o inimigo. A mesma lógica opera em ambos os casos: consubstanciais (esposa e filhos no primeiro caso; o matador no segundo) não podem comer, pois isso seria autocanibalismo.

17 O formato do diagrama se apóia em Gell (1999).

18 Referindo-se à recepção violenta dos mortos pelos Maï, os Araweté, bastante explicitamente, “comparariam essa recepção agressiva por parte dos deuses ao que eles próprios costumavam fazer quando encontravam caçadores brancos na floresta antes do contato" (Viveiros de Castro 1992:211).

19 Em geral, todos os processos a que os mortos (como aspectos da pessoa) são submetidos têm um correspondente corporal equivalente: cozimento, consumo da carne, dos ossos, putrefação ou transformação em animais (ver Vilaça 1992:247; Viveiros de Castro 1992, cap. 7; Descola 1997:367).

20 “As almas dos inimigos, ao chegarem ao céu, são arremessadas de volta à terra, onde perecem definitivamente. Nesse sentido, os inimigos só têm ou são ta'o we: mortíferos, são mortais [...]. [I]nimigos, não sendo propriamente humanos, não têm a alma celeste, princípio da pessoa." (Viveiros de Castro 1992:238)

${ }^{21}$ Recordemos que ser um O utro não é a mesma coisa que ser um objeto. Os Maï podem temer os Iraparadï, mas não são objeto de troca ou consumo. N esse sentido, poderíamos dizer que sua posição de sujeito é desafiada, mas não revertida.

22 Tomo essa idéia de Viveiros de Castro (1992): para os Tupinambá, um dos objetivos da guerra ritual era inverter a posição uxorilocal e dominada dos homens casados. Guerreiros importantes não viviam uxorilocalmente, era uma honra darIhes mulheres; eles lideravam grupos de guerreiros. Virilocais, tomadores de espo- 
sa e líderes, encarnavam tudo o que um jovem não é, mas aspira ser. Essa inversão (alteração [othering]) é a mesma que caracteriza os deuses M aï dos A raweté, tomadores de esposa celestiais que não retribuem. Essas duas posições, líder tupinambá e deus Maï, são, assim, condições finais para as quais todos são "atraídos".

$23 \mathrm{M}$. Strathern escreveu ela mesma sobre os paralel os entre o perspectivismo de Viveiros de Castro e seus próprios pontos de vista sobre a troca de dons melanésia (Strathern 1999:249-256). Se a compreendo corretamente, ela focalizou o modo como o dom melanésio é, em certo sentido, o equivalente da visão amazônica como meio de efetuar trocas de perspectiva: “Dons nas mãos poderiam ser quase como os ol hos amazônicos" (Strathern 1999:254). A qui, porém, privilegio os paralelos sugeridos pelo conceito de dividualidade [dividuality].

${ }^{24}$ A lúcida apresentação da teoria do perspectivismo por Viveiros de Castro (1998) diz pouco sobre o tema da troca real ou imaginária de partes corporais ou outros objetos. Em algumas partes da Melanésia, a troca de mulheres parece basear-se na mesma lógica que a troca de dons (Strathern 1988; 1992). Viveiros de Castro, ao associar canibalismo e troca de mulheres, deixou o terreno aberto a uma exploração mais detalhada da troca de partes do corpo.

25 Quero agradecer a Viveiros de Castro por me chamar a atenção para este ponto. 


\section{Referências bibliográficas}

CARNEIRO DA CUNHA, Manuela. 1978. Os M ortos e os Outros. São Paulo: Editora Hucitec.

DESCOLA, Phillippe. 1997. The Spears of Twilight: Life and Death in the A mazon J ungle. London: Flamingo, HarperCollins.

FAUSTO, Carlos. 2000. "Of Enemies and Pets: Warfare and Shamanism in Amazonia". American Ethnologist, 26(4):933-956.

GELL, Alfred. 1999. "Strathernograms or the Semiotics of Mixed Metaphors". In: E. Hirsch (org.), The Art of Anthropology: Essay and Diagrams. London: The Athlone Press. pp. 29-75.

MAYBURY-LEWIS, David. 1979. Dialectical Societies: The Gê and the Bororo of Central Brazil. Massachusetts: Harvard University Press.

RIVIĖRE, Peter. 1984. Individual and Society in Guiana. Cambridge: Cambridge University Press. . 1994. "WYSINWYG in Amazonia". J ournal of the A nthropological Society of Oxford, 25(3):255-262.

SEEGER, Anthony, DAMATTA, Roberto e VIVEIROS DE CASTRO, Eduardo. 1979. “A Construção da Pessoa nas Sociedades Indígenas Brasileiras". Boletim do M useu N acional, 32:120.

STRATHERN, Marilyn. 1988. The Gender of the Gift: Problems with Women and Problems with Society in Melanesia. Berkeley: University of California Press.

. 1992. “Qualified Value: The Perspective of Gift Exchange". In: C. Humphrey e S. Hugh-J ones (orgs.), Barter, Exchange and Value: An Anthropological Approach. Cambridge:
Cambridge University Press. pp. 169-191.

. 1999. Property, Substance and Effect: Anthropological Essays on Persons and Things. London: The Athlone Press.

TAYLOR, Anne Christine. 1996. “The Soul's Body and its States: An Amazonian Perspective on the Nature of Being Human". J ournal of the Royal Anthropological Institute, 2(2): 201-216.

TURNER, Terrence. 1995. “Social Body and Embodied Subject: Bodiliness, Subjectivity and Sociality among the Kayapo". Cultural Anthropology, 10(2):143-170.

VILAÇA, A parecida. 1992. Comendo como Gente: Formas do Canibalismo Wari' (Pakaa Nova). Rio de J aneiro: Anpocs/Editora UFRJ .

VIVEIROS DE CASTRO, Eduardo. 1992. From the Enemy's Point of View. Chicago: Chicago University Press. . 1998. "Cosmological Deixis and Amerindian Perspectivism". J ournal of the Royal Anthropological Institute, 4(3):469-488. 


\section{Resumo}

Este artigo explora a idéia de fractalidade, juntamente com uma de suas principais propriedades, a auto-similaridade escalar. A noção de "personitude fractal" é proposta como um modo de pensar a pessoa ameríndia. Quando se fala aqui em personitude fractal, tem-se em mente o encerramento de pessoas em partes de pessoas e a replicação da relação entre Eus e Outros em diferentes escalas (intrapessoal, interpessoal e intergrupal). Três casos etnográficos ameríndios (araweté, wari' e tupinambá) são comparados e analisados, combinando-se proposições da teoria da troca melanésia e da teoria do perspectivismo ameríndio de modo a revelar a utilidade da personitude fractal como instrumento analítico.

Palavras-chave Amazônia, Perspectivismo, Pessoa, Fractalidade, Teoria da Troca

\section{Abstract}

This essay explores the potential of the idea of fractality along one of its properties: scaled self-similarity. The notion of fractal personhood is proposed as a way of thinking about the Amerindian person. When speaking of fractal personhood what is meant is the containment of whole persons in parts of persons and the replication of relations between selves and alters at different scales (intra-personal, inter-personal and inter-group). Three Amerindian ethnographies (Araweté, Wari' and Tupinamba) are compared and analysed combining propositions from M elanesian exchange theory and a theory of A merindian perspectivism in order to elicit the usefulness of "fractal personhood" as an analytical tool.

Key words Amazonia, Perspectivism, Personhood, Fractals, Exchange Theory 